\title{
The Origin and Current Meanings of "Judicial Activism"
}

\author{
Keenan D. Kmiec ${ }^{\dagger}$
}

\section{TABLe of Contents}

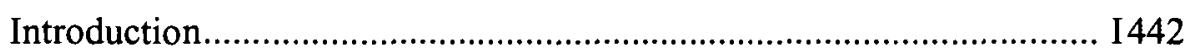

I. Early History of the Term "Judicial Activism"............................. I4444

A. In Search of the Earliest Use.................................................. 1444

B. First Recorded Use: Arthur Schlesinger in

Fortune Magazine

C. Early Usage of "Judicial Activism"....................................... 1450

D. Early Scholarly Examination of Judicial Activism.................... 1452

E. First Judicial Use of "Judicial Activism": Judge Joseph C. Hutcheson, Jr.

F. Other Noteworthy Discussions of "Judicial Activism" in Judicial Opinions

II. Definitions of Judicial Activism

A. Striking Down Arguably Constitutional Actions of Other Branches

B. Ignoring Precedent............................................................ 1466

1. Vertical versus Horizontal Precedent..................................... 1466

2. Constitutional versus Statutory versus Common

Law Precedents

C. Judicial Legislation

D. Departures from Accepted Interpretive Methodology

E. Result-Oriented Judging

Copyright $(\mathcal{O} 2004$ California Law Review, Inc. California Law Review, Inc. (CLR) is a California nonprofit corporation. CLR and the authors are solely responsible for the content of their publications.

$+\quad$ J.D., School of Law, University of California, Berkeley (Boalt Hall), May 2004; law clerk for the Honorable Samuel A. Alito, Jr. I wish to thank my family (especially my father) for its love and support; my Boalt professors (especially Vik Amar, Jesse Choper, Harry Scheiber, Robert Merges, and Donna Petrine) for giving an eager mind much to ponder; and my friends and colleagues at the California Law Review (especially my fellow Articles Editors) for their dedieation, enthusiasm, and kindness. 


\title{
The Origin and Current Meanings of "Judicial Activism"
}

\author{
Keenan D. Kmiec
}

\section{INTRODUCTION}

Speaking at a recent symposium, Judge Frank Easterbrook opened with an ostensibly safe sentence: "Everyone scorns judicial activism, that notoriously slippery term." Yet even this observation cannot go unqualified. Most would agree that judicial activism is indeed slippery. But some scholars, ${ }^{2}$ including at least one sitting Supreme Court Justice, ${ }^{3}$ have suggested that in some contexts, it is not always a bad thing. This is the problem: one can scarcely make an observation about judicial activism today without appending definitions, provisos, and qualifications.

During the 1990s, the terms "judicial activism"4 and "judicial activist" appeared in an astounding 3,815 journal and law review articles. ${ }^{5}$ In the first four years of the twenty-first century, these terms have surfaced in another 1,817 articles-an average of more than 450 per year. ${ }^{6}$ Judges today are far more likely to accuse their colleagues of judicial activism than

1. Frank H. Easterbrook, Do Liberals and Conservatives Differ in Judicial Activism?, 73 U. CoLo. L. REV, 1401, 1401 (2002) (internal quotations omitted).

2. See, e.g., Sterling Harwood, Judicial Activism: A Restrained Defense (1996); Fredrick P. Lewis, The Context of Judicial Activism: The Endurance of The Warren Court Legacy in a Conservative Age (1999); see also Arthur S. Miller, For Judicial Activism, N.Y. Times, Nov. 11, 1979, at E21. For a clever recent twist on advocacy of judicial activism, see Stephen F. Smith, Activism as Restraint: Lessons from Criminal Procedure, 80 TEx. L. Rev. 1057 (2002).

3. In a short article, Justice John Paul Stevcns describes a scries of cases commonly viewed as "activist," and concludes, "[b]ecause 1 did not participate in any of the foregoing cases, 1 cannot be entirely sure about how 1 would have voted, but with the benefit of hindsight I can say that 1 now agrec with each of those examples of judicial activism." John Paul Stevens, Judicial Activism: Ensuring the Powers and Freedoms Conceived by the Framers for Today's World, C.B.A. REc., Oct. 16, 2002, at 26.

4. Throughout this Comment, references to the term "judicial activism" will include the term in its personified form, "judicial activist," and its plural form, "judicial activists." Similar terms, likc "Lochnerization," "spurious interpretation," and "judicial legislation," are only addressed insofar as they are related to discussions of judicial activism. See, e.g., infra Part I.A.

5. Westlaw search ["judicial activist" "judicial activism" "judicial activists" \& DA(AFT) 12/31/1989 \& BEF 1/1/2000] in "Joumals and Law Reviews" database, performed by author on August $19,2004$.

6. Westlaw search ["judicial activist" "judicial activism" "judicial activists" \& DA(AFT) 12/31/1999 \& BEF 1/1/2004] in "Journals and Law Reviews" database, performed by author on August I9, 2004. 
they were in prior decades. ${ }^{7}$ And the term has assumed a prominent role in public debates, appearing regularly in editorial pages, ${ }^{8}$ Web "blogs," political discussion, and confirmation battles.

Ironically, as the term has become more commonplace, its meaning has become increasingly unclear. This is so because "judicial activism" is defined in a number of disparate, even contradictory, ways; scholars and judges recognize this problem, yet persist in speaking about the concept without defining it. Thus, the problem continues unabated: people talk past one another, using the same language to convey very different concepts.

This Comment does not seek to attack or defend any particular notion of judicial activism, nor does it proffer an entirely new theory of the term. Instead, it modestly assembles theories of judicial activism that have gained widespread acccptance, linking them to history, caselaw, and other scholarship. Its purpose is to clarify the meaning of "judicial activism" when it is used in different contexts, so that those who use the term can communicate their ideas more effectively.

To achieve this end, this Comment begins by exploring the neglected history of the concept of judicial activism. Over half a century ago, a scholar wrote that he lived in "a day that hears much talk of judicial activism," and thirty years ago, Judge Friendly wrote that he lived in the "days of judicial activism." "I Yet basic questions about the term remain unanswered: Who was the first to use it? What did it mean initially? Which scholars and judges ushered it from obscurity to ubiquity?

Part I recounts several important and heretofore unexplored moments in the history of the term "judicial activism." It analyzes perhaps the earliest published work to mention it, two of the first scholarly articles devoted to it, and the first judicial opinions to invoke it. This Part demonstrates that from the beginning, there was no single, accepted definition of "judicial activism." The term has always embodied a variety of concepts, and it is imperative that speakers explain which meaning they seek to employ.

7. The term appeared in judicial opinions only twice in the 1950s and fourteen times in the $1960 \mathrm{~s}$, while judges found occasion to invoke it 262 times during the $1990 \mathrm{~s}$.

8. In the past decade (from August 1994 to August 2004), "judicial activism" and its cognates have appeared 163 times in the Washington Post, and another 135 times in the New York Times. Lexis search ["judicial activism" or "judicial activist" or "judicial activists" and date(geq (7/31/1994) and leq $(8 / 1 / 2004))]$ in "Washington Post" and "New York Times" databases, respectively, performed by author on Aug. 19, 2004.

9. A blog is a Web page consisting of chronological, frequently updated posts. It resembles an online journal. Many blogs focus on a specific subject such as appellate law, criminal procedure, or Supreme Court cases. To see an example of the remarkable abilities of "bloggers" to eomment quickly and intelligently on current issues, consult the November 15, 2002 blog post labeled "Judicial Activism Revisited" at http://www.jeffcoop.com/blog/archives/2002_11.html (last visited Aug. 19, 2004) (describing, commenting on, and providing links to an explosion of commentary on judicial aetivism within a single week across the lnternet, triggered by a single editorial in the New York Times).

10. J.D. Hyman, Segregation and the Fourteenth Amendment, 4 VAND. L. REv. 555, 555 (1950).

11. Assoc. Indus. of N.Y. State, Inc. v. U.S. Dep't of Labor, 487 F.2d 342, 354 (2d Cir. 1973). 
Part II turns from history to modern uses of the term "judicial activism," surveying the range of meanings and applications it has acquired. It fleshes out the definitions suggested in Part I while integrating comments from prominent scholars, instructive lower court cases, and Supreme Court cases. This Part identifies five core meanings of "judicial activism": (I) invalidation of the arguably constitutional actions of other branches, (2) failure to adhere to precedent, (3) judicial "legislation," (4) departures from accepted interpretive methodology, and (5) result-oriented judging.

Some scholars have suggested that in its present state, "judicial activism" is a virtually empty term. ${ }^{12}$ They rightly point out that by itself, the label carries Iittle more than a pejorative connotation. Absent substantial context, even a well-meaning listener often cannot gloss a deeper meaning. This Comment argues, however, that when "judicial activism" is clearly defined, it can function as an instrument for constructive discussion. Discussions about "judicial activism" invite subsidiary questions that move the debate beyond soundbytes and name-calling, and toward meaningful legal discourse. As Part I will show, early treatments of the term evince a refreshing optimism about its potential to help the legal community and the public to better understand the nature of judicial decision making. If we tread carefully, there is still reason to share that hope.

EARLy History OF THE TERm "Judicial ACTIVISM"

\section{A. In Search of the Earliest Use}

The idea of judicial activism has been around far longer than the term. ${ }^{13}$ Before the twentieth century, legal scholars squared off over the concept of judicial legislation, that is, judges making positive law. ${ }^{14}$ "Where Blackstone favored judicial legislation as the strongest characteristic of the common Iaw, Bentham regarded this as an usurpation of the legislative function and a charade or "miserable sophistry.",15 Bentham, in turn, taught John Austin, who rejected Bentham's view and

12. See, e.g., Randy E. Bamett, Is the Rehnquist Court an "Activist" Court? The Commerce Clause Cases, 73 U. Colo. L. Rev. 1275, 1275-76 (2002); cf. Peter Westen, The Empty Idea of Equality, 95 HaRv. L. Rev. 537 (1982).

13. For an excellent sketch of judicial critiques throughout the Twentieth Century, see Michael Gerhardt, The Rhetoric of Judicial Critique: From Judicial Restraint to the Virtual Bill of Rights, 10 WM. \& MARY BiLl RTS. J. 585 (2002).

14. See, e.g., Ezra R. Thayer, Judicial Legislation: Its Legitimate Function in the Growth of the Common Law, 5 HARV. L. REV. 172 (1891) (deseribing "judicial legislation" as "the growth of the law at the hands of judges ...."). It should be noted that many of these discussions define "judicial legislation" in similarly vague terms.

15. Brian Bix, Positively Positivism, 85 VA. L. Rev. 889, 907 n.108 (1999) (book review) (quoting Richard A. Cosgrove, Scholars of the Law: English Jurisprudence from Blackstone to Hart 56-57 (1996)). 
defended a form of judicial legislation in his famous lectures on jurisprudence. ${ }^{16}$ In the first half of the twentieth century, a flood of scholarship discussed the merits of judicial legislation, and prominent scholars took positions on either side of the debate. ${ }^{17}$

Criticism of constitutional judicial legislation was particularly vehement during the Lochner ${ }^{18}$ era. Critics assailed the Court's preference for business interests as it repeatedly struck down social legislation in the name of substantive Due Process. ${ }^{19}$ While some modern scholars consider Lochner and its progeny virtually synonymous with "judicial activism,"20 the term is conspicuously absent from contemporaneous criticism. The New Deal and the "revolution" of 1937 ushered in another spate of critical commentary, but again, contemporaneous literature does not mention "judicial activism" by name. Years later, after the justices agreed that the New Deal was on firm constitutional ground, the term finally surfaced in legal discourse.

\section{B. First Recorded Use: Arthur Schlesinger in Fortune Magazine}

One might expect that the term "judicial activism" first appeared in a respected judge's dissent, or in a seminal law review article. This does not appear to be the case. ${ }^{21}$ Rather, somewhat fittingly, the first use of the term

16. For a discussion of Austin's views on judicial legislation and their various misinterpretations over the years, see W. L. Morrison, Some Myth About Positivism, 68 YALE L.J. 212, 214 (1958) ("The whole of [Austin's] Lecture XXXVIll seeks to demonstrate that some common objections to judicial legislation are groundless.").

17. See, e.g., Benjamin N. Cardozo, The Nature of the Judicial Process (1921) (describing how judges "make" law). Compare Kent Greenawalt, Discretion and Judicial Decision: The Elusive Quest for the Fetters that Bind Judges, 75 Colum. L. REv. 359 (1975) ("[Cardozo's] characteristically eloquent formulation of the thesis that judges 'legislate' reflects its widespread acceptance among jurisprudential writers of his time . . ."), with Legislation, 43 HARV. L. REv. 1302, 1304 (1930) (quoting Roscoe Pound, Spurious Interpretation, 7 CoLuM. L. REv. 379 (1907), for the proposition that "[e]xtensive exercise of the powers of judicial legislation is frowned upon by the bar ....").

18. See Lochner v. New York, 198 U.S. 45 (1905).

19. See generally William G. Ross, A Muted Fury: Populists, Progressives, and Labor Unions Confront the Courts, 1890-1937 (1994).

20. See, e.g., James W. Ely, Jr., Economic Due Process Revisited, 44 VAND. L. REv. 213, 213-14 (1991) (book review); Cass R. Sunstein, Lochner's Legacy, 87 CoLuM. L. REv. 873, 874 (1987) ("The received wisdom is that Lochner was wrong because it involved 'judicial activism': an illegitimate intrusion by the courts into a realm properly reserved to the political branches of government."). Judges regularly invoke Lochner as a way of criticizing their colleagues' opinions. See, e.g., Coll. Sav. Bank v. Fla. Prepaid Post Secondary Educ. Expense Bd., 527 U.S. 666, 690 (1999); Seminole Tribe v. Florida, 517 U.S. 44, 166 (1996) (Souter, J., dissenting); United States v. Lopez, 514 U.S. 549, 601 n.9 (1995) (Thomas, J., concurring); Dolan v. City of Tigard, 512 U.S. 374, 406-09 (1994) (Stevens, J., dissenting); TXO Prod. Corp. v. Alliance Res. Corp., 509 U.S. 443, 455 (1993) (Stevens, J.) (plurality opinion); Planned Parenthood v. Casey, 505 U.S. 833, 959-61 (1992) (Rebnquist, C.J., dissenting).

21. Substantial research by the author has failed to produce any earlier references to "judicial activism." While proof by induction is hardly foolproof, at least one other authority attributes the term "judicial activism" to Schlesingcr. See Albon P. Man, Jr., Mr. Justice Murphy and the Supreme Court, 36 VA. L. REV, 889, 890, 916 (1950). 
to attract substantial attention from the public occurred in a popular magazine, in an article meant for a general audience written by a non-lawyer.

Arthur Schlesinger Jr. introduced the term "judicial activism" to the public in a Fortune magazine article in January $1947 . .^{22}$ Schlesinger's article profiled all nine Supreme Court justices on the Court at that time and explained the alliances and divisions among them. The article characterized Justices Black, Douglas, Murphy, and Rutlege as the "Judicial Activists"23 and Justices Frankfurter, Jackson, and Burton as the "Champions of Self Restraint."24 Justice Reed and Chief Justice Vinson comprised a middle group. ${ }^{25}$

By 1947, none of the justices openly questioned the constitutionality of the New Deal. lnstead, the Court split over the interpretation of legislation and "the proper function of the judiciary in a democracy."26 Schlesinger describes the competing approaches:

This conflict may be described in several ways. The Black-Douglas group believes that the Supreme Court can play an affirmative role in promoting the social welfare; the Frankfurter-Jackson group advocates a policy of judicial self-restraint. One group is more concerned with the employment of the judicial power for their own conception of the social good; the other with expanding the range of allowable judgment for legislatures, even if it means upholding conclusions they privately condemn. One group regards the Court as an instrument to achieve desired social results; the second as an instrument to permit the other branches of government to achieve

22. Arthur M. Schlesinger, Jr., The Supreme Court: 1947, ForTune, Jan. 1947, at 202, 208. Regardless of whether Schlesinger's article was actually first to use the term, it is indisputably a seminal piece. Many of the other early scholarly articles that use the term directly cite the Schlesinger article. See, e.g., Abraham S. Goldstein, Eugene v. Rostow as Dean: 1955-1965, 94 YALE L.J. 1323, 1323 (1985); Note, Mr. Justice Reed-Swing Man or Not?, I STAN. L. REv. 714, 718 (1949); Note, Negligence-Res Ipsa Loquitur-Application to Master-Servant Relationship When Fellow-Servant Rule Abolished, I VAND. L. REv. 662, 664 n.13 (1948). Another oft-cited early work that mentions "judicial activism" is C. Herman Pritchett, The Roosevelt Court: A Study in Judicial Politics AND VALues 1937-1947 (1948). Pritchett's book repeatedly mentions "judicial activism," but always with a citation to Schlesinger's article. See id. at 28-29, 266, $290 \mathrm{n} .1$ (1948). Thus, many of the other early works that mention "judicial activism" in the context of Pritchett's book can be attributed to the Schlesinger article as well. See, e.g., J. Francis Paschal, 35 VA. L. Rev. 128, 130 (1949) (reviewing Pritchett, supra); Earl Latham, 14 LaW \& Contemp. Probs. 537, 543 (1949) (same); Walter P. Armstrong, 24 1ND. L.J. 308, 313 (1949) (same); Pendleton Howard, 23 S. CAL. L. Rev. I65, 167 (1949) (same).

23. Schlesinger, supra note 22 , at 74-76.

24. Id. at 76-77. Schlesinger included Justice Burton, the only Republican appointed to the Supreme Court from 1933 to 1953, among the Champions of Self Restraint on the basis of very little evidence. Burton was sworn in on October 1, 1945, and had yet to become fully embroiled in the controversy. However, Schlesinger's label proved accurate: Justice Burton "was found most often concurring with those Justices who believed that the Court should use restraint in the exercise of its great powers to declare statutes unconstitutional and to impose federal standards upon the states." Notes: In Memoriam - Harold Hitz Burton, 78 HARv. L. Rev. 799, 799 (1965).

25. Schlesinger, supra note 22 , at 78 .

26. Id. at 201 . 
the results the people want for better or worse. In brief, the Black-Douglas wing appears to be more concerned with settling particular cases in accordance with their own social preconceptions; the Frankfurter-Jackson wing with preserving the judiciary in its established but limited place in the American system. $^{27}$

Each side that Schlesinger portrayed in Fortune is the product of a distinct legal world-view. The Black-Douglas view has its roots in the Yale Law School, which had strong ties to both Black and Douglas. ${ }^{28}$ This view perceived legal reasoning as malleable, rather than scientific. ${ }^{29}$ As Schlesinger describes, the Yale Law School "Judicial Activist" camp believed and wrote that "[ $t]$ he resources of legal artifice, the ambiguity of precedents, the range of applicable doctrine, are all so extensive that in most cases in which there is a reasonable difference of opinion a judge can come out on either side without straining the fabric of legal logic." ${ }^{\prime 30}$ In short, there are no unassailable "right" answers, and policy concerns move to the forefront. "A wise judge," if he accepts this philosophy, "knows that political choice is inevitable; he makes no false pretense of objectivity and consciously exercises the judicial power with an eye to social results."

Schlesinger's Judicial Activists believe that law and politics are inseparable. They see judicial decisions as "result-oriented," because no result is foreordained. They adopt the famous Learned Hand dictum that "the words a judge must construe are 'empty vessels into which he can pour nearly anything he will." 32 From this perspective, the Frankfurter-Jackson ideal of judicial restraint begins to look like abdication of responsibility; "deference" to the legal status quo becomes a decision to favor the interests positioned to benefit from that status quo. According to the Judicial Activists, Schlesinger writes, "The Court cannot escape politics: therefore, let it use its political power for wholesome social purposes." ${ }^{33}$ Judicial selfrestraint is "at best a mirage." 34

Schlesinger explains that the Champions of Self Restraint, on the other hand, are more skeptical of individual judges' notions of justice. To them, laws have fixed meanings, and deviation from those meanings is inappropriate, no matter which groups may benefit from the departure. As a logical matter, they claim, "[i]t is not clear that Black's solicitude for labor unions is per se more reprehensible than [Justice] Pierce Butler's, say, for

\footnotetext{
27. Id.

28. Id. (Douglas taught there and Black sent his son there).

29. Id. (pointing to the work of Thurman Arnold, Fred Rodell, and Walton H. Hamilton as being influential).

30. Id.

31. Id.

32. Id.

33. Id. at 202 .

34. Id.
} 
railroad companies." ${ }^{35}$ At its heart, then, the Frankfurter-Jackson school seeks "to resist judicial supremacy, either of the right or of the left, in the name of deference to the legislative will, ${ }^{336}$ and rests on faith in the separation of powers and the democratic process. ${ }^{37}$ The Champions of Judicial Restraint, according to Schlesinger, understand the judicial role much as Justice Holmes did. ${ }^{38}$ "If the legislature makes mistakes, it is up to the legislature to remedy them. Any other course will sap the vigor of our democracy by encouraging legislatures in an irresponsibility based on an expectation that the courts will backstop their wild pitches." ${ }^{39}$

The Frankfurter-Jackson view is predicated on the belief that all law is not politics. These justices might have conceded that there are many close cases, but they believed that common law, statutes, and the Constitution are not "empty vessels." There is meaning, they would assert, and there are right answers. Just as importantly, they thought that because reasonable people can hold vastly different notions of justice, it is unfair and unjustifiable to force one's view upon others. Any attempt to do so would lead "toward a state of judicial despotism that [would] threaten[] the democratic process." 40

Schlesinger nicely pits these opposing views in a dialogue against one another, calling Frankfurterian judicial restraint "self-denial":

Self-denial has thus said: the legislature gave the law; let the legislature take it away. The answer of judicial activism is: in actual practice the legislature will not take it away-at least until harm, possibly irreparable, is done to defenseless persons; therefore the Court itself must act. Self-denial replies: you are doing what we all used to condemn the old Court for doing; you are practicing judicial usurpation. Activism responds: we cannot rely on an

35. Id.

36. Id. at 204.

37. For classic Frankfurterian discussions of judicial restraint, see Am. Fed'n of Labor v. Am. Sash \& Door Co., 335 U.S. 538, 553 (1949); Lincoln Fed. Labor Union v. Northwestern Iron \& Metal Co., 335 U.S. 525 (1949); and Bd. of Educ. v. Barnette, 319 U.S. 624 (1943). But see Mark B. Rotenberg, Politics, Personality and Judging: The Lessons of Brandeis and Frankfurter on Judicial Restraint, 83 Colum. L. Rev. 1863, 1864 (1983) (reviewing H.N. Hirsch, The Enigma of Felix FRANKFURTER (1981)) ("Propounding a 'rigidly austere doctrine' of judicial restraint, Hirsch alleges, was not only disingenuous and artificial for a judge with Frankfurter's background of frenetic activism on behalf of countless legal and political causes, but also internally inconsistent and ultimately absurd.").

38. Schlesinger also traces this dispute to the differences between the judicial philosophies of Justices Holmes and Brandeis. To put it bluntly, "Holmes believed that if the American people wanted to go to hell, he could not see anything in the Constitution to stop them." Schlesinger, supra note 22, at 208. Brandeis "would require [legislation] to conform to certain standards of social wisdom." Id. In short, "Holmes wanted to make sure that the people could embody their desires in law, whatever the nature of the desires, while Brandeis could never relieve himself of a sense of responsibility for the results of judicial decision. This is the essence of the current struggle." Id.

39. Schlesinger, supra note 22 , at 204 .

40. Id. 
increasingly conservative electorate to protect the underdog or to safeguard basic human rights; we betray the very spirit and purpose of the Constitution if we ourselves do not intervene. ${ }^{41}$

This exchange is remarkable for its prescience and timelessness. It has been replayed in slightly different words for decades in legal classrooms, public fora, and scholarly journals. Concerns about failures of the political process, basic human rights, and the ghost of Lochner are just as central and urgent in 2004 as they were in 1947.42

After describing these opposing factions, Schlesinger takes sides. While he sympathizes with the Black-Douglas wing of the Court, he perceives a threat to democracy inherent in their position, and ultimately prefers to limit "judicial activism" to civil liberties cases. He counsels that "basic decisions on all questions save fundamental rights of political agitation be entrusted as completely as possible to institutions directly responsible to popular control. ${ }^{.43}$ This, of course, is a variant of the position taken by Justice Stone in footnote four of United States $v$. Carolene Products $\mathrm{Co}^{44}$ Schlesinger's theory even hints at the importance of procedurally-based democratic values, which became the centerpiece of John Hart Ely's seminal book, Democracy and Distrust, over thirty years later ${ }^{45}$

Schlesinger's article contributes to legal scholarship and popular debate as the first significant commentary on "judicial activism." Schlesinger suggests the layers of the clash: unelected judges versus democratically enacted statutes; results-oriented judging versus principled decisionmaking; strict versus creative use of precedent; democratic supremacy versus human rights; law versus politics; and other equally fundamental dichotomies. Yet, even this initial effort exhibits some of the symptoms of the classic malady that has infected modern discussions of judicial activism. Schlesinger fails to define his terms with precision. For example, would

41. Id. at 206.

42. One need only look to the vitriol and accolades that followed Lawrence v. Texas, 539 U.S. 558 (2003), to rcalize that these concepts remain intense sources of disagreement. Compare Jeffrey Rosen, Sex Appeal, New RePublic ONLINE, at https://ssl.tnr.com/p/ docsub.mhtml? i=express\&s=rosen 063003 (last visited Aug. 19, 2004) ("Yes, as a constitutional matter, Lawrence is worse than Roe."), with Sherry Colb, Welcoming Gay People Back into the Fold: The Supreme Court Overrules Bowers v. Hardwick, at http://writ.news.findlaw.com/colb/20030630.html (June 30, 2003).

43. Schlesinger, supra note 22 , at 208.

44. 304 U.S. 144, $152 \mathrm{n} .4$ (1938) (suggesting that the Court employ a narrower "presumption of constitutionality" for legislation that may implicate the rights of certain politieal minorities); see also Louis F. Powell, Jr., Carolene Products Revisited, 82 Colum. L. Rev. 1087, 1087 (1982) (describing the background and importance of the "most celebrated footnote in constitutional law").

45. See John Hart Ely, Democracy and Distrust: A Theory of Judicial Review (1980) (proposing a solution to the countermajoritarian difficulty raised by Carolene Products through the idea of representation-reinforcement); see also Edward White, The Arrival of History in Constitutional Scholarship, 88 VA. L. REv. 485, 548-58 (2002) (providing an overview of Professor Ely's ideas in an historical context). 
Bush v. Gore ${ }^{46}$ or Roe v. Wade ${ }^{47}$ qualify as "judicial activism" according to Schlesinger? If so, why? Because they (arguably) exhibited a lack of deference to the political branches? Because they were (arguably) departures from precedent? Because they (arguably) qualified as judicial legislation? Or perhaps because they were (arguably) result-oriented? Schlesinger never explains what characteristic would make a decision "activist."48 Instead, he ascribes so many attributes to the Judicial Activists and the Champions of Self Restraint that it is impossible to determine which ones are necessary, sufficient, or superfluous. Of course, this Iine of questioning is unfair: "Judicial activism" had no established (or competing) definitions when Schlesinger used it. Nevertheless, to the modern eye, the ambiguity in Schlesinger's article is frustrating.

Imprecision aside, Schlesinger had good reason to end his article on a positive note. He penned a thought-provoking, constructive, and balanced article on a topic of great public importance. As he saw it, "[ $t]$ he conflict on the Court, if it can be restrained from intellectual and personal extremes, may lead to a debate in the most fruitful tradition of American political thought." 49 Though current discussions of judicial activism often fail to live up to this high standard, Schlesinger gave the concept a promising start.

\section{Early Usage of "Judicial Activism"}

As discussed above, Schlesinger alluded to a number of meanings when he wrote of "judicial activism." Many of these definitions are quite similar to those used today. For instance, scholars often label the

46. 531 U.S. 98 (2000) (per curiam).

47. 410 U.S. $113(1973)$.

48. Laurence Tribe elegantly captures the difficulty of this inquiry in his discussion of Bush v. Gore. See Laurence Tribe, EROG v. HSUB and its Disguises: Freeing Bush v. Gore from its Hall of Mirrors, 115 HaRv. L. REv. 170, 300 (2001). Tribe considers the possibility that a future "[c]ourt could treat Bush v. Gore as an object lesson counseling against judicial 'activism' in those cases in which ." He continues,

My own favorite filler for the blank in the preceding paragraph would use Bush v. Gore to counsel against judicial activism in cases in which such textual and structural guidance as the Constitution provides points toward permitting the political branches to resolve the dispute under procedures at least sketched, if not fully spelled out, by the Constitution itself and by statutes or treaties promulgated pursuant to it; in which there is no clearly threatened violation of any constitutional right that the political branches are structurally incapable of, or indisposed toward, protecting; in which taking jurisdiction away from the political branches in the circumstances presented would yield no coherent remedy for whatever right is said to be threatened; in which the contemplated judicial action would serve to entrench the power of the political party or group seeking such action rather than to protect relatively powerless individuals or groups from the entrenched power of others; or in which the judicial action in question would advance the interests of the controlling majority on the Court in some extrinsic way, as by assuring the nomination of like-minded replacements. Bush v. Gore fails on all five counts.

Id. at 300-301.

49. Schlesinger, supra note 22, at 21 (stating further that the wise resolution of this debate "could easily make this Court, with its remarkable abilities and its agreement on a wide range of constitutional fundamentals, one of the great creative Courts of history."). 
overturning of democratically enacted statutes as "judicial activism," much like Schlesinger did. ${ }^{50}$ However, one other early meaning of the term has not prevailed in modern usage: "judicial activist" as a term of endearment.

In its early days, the term "judicial activist" sometimes had a positive connotation, much more akin to "civil rights activist" than "judge misusing authority." Take, for example, references to the late Justice Frank Murphy. Albon P. Man observed that "Murphy's votes in civil rights cases reflect not only his objectivity and independence as a judge but also his position as perhaps the outstanding judicial activist on the Court." 51 Alfred L. Scanlan offered similar praise for Justice Murphy's judicial activism in civil rights issues, answering the criticism that such activism is undemocratic by replying,

We sanction the decisions of the rule of the majority when they come from the duly and democratically elected representatives of the people. When that majority will tries to undercut or impair the basic principles upon which it rests, namely, the free play of opposing views, practices, parties, etc., then the Court, as guardian of the Bill of Rights, must step in. We will not tolerate democracy to be destroyed in its own name. Justice Murphy grasped that. ${ }^{52}$

The label of "judicial activist" is unmistakably a compliment in this context, reflecting a belief that one ought to aggressively employ judicial review to safeguard the rights upon which democracy is predicated. ${ }^{53}$ Scholars sometimes referred to Justices Brandeis and Cardozo in much the same way. For example, a 1949 article observed, "Mr. Brandeis was a pragmatic judicial activist who saw in the courts a powerful instrument to

50. Compare Christopher Peters, Adjudication as Representation, 97 CoLum. L. Rev. 312, 434 (1997) (" $[C]$ harges of judicial activism are often leveled when a court strikes down a democratieally enacted statute; this indeed is the most frequent target of Judge Bork's criticism.") (eiting ROBERT H. Bork, The Tempting of America 17 (1990)), with Schlesinger, supra note 22, at 208 ("For the removal of unwise laws from the statute books appeal lies not to the courts but to the ballot and to the processes of democratic government.") (quoting Harlan Fiske Stone as an example of judicial restraint, in opposition to judicial activism).

51. Albon P. Man, Jr., Mr. Justice Murphy and the Supreme Court, 36 VA. L. Rev. 889, 916 (1950). Justice Rutledge has also been described in this manner. See Lester E. Mosher, Mr. Justice Rutledge's Philosophy of Civil Rights, 24 N.Y.U. L.Q. REv. 661, 667-68 (1949) (describing Justice Rutledge as a judicial activist in civil rights matters, while exercising judicial self-restraint in economic matters).

52. Alfred L. Scanlan, The Passing of Justice Murphy-The Conscience of a Court, 25 NoTRE DAME L. Rev. 7,38 (1949).

53. A somewhat tempered version of this view still has purchase today. See, e.g., LAURENCE H. Tribe \& Michael C. Dorf, On Reading the Constitution (1991); Harry H. Wellington, INTERPRETING THE CONSTITUTION (1990); cf. Christopher Wolfe, The Result-Oriented Adjudicator's Guide to Constitutional Law, 70 TEx. L. REv. 1325, 1325 (1992) (book review) ("Whatever the motivation, Laurence Tribe and Michael Dorf and Harry Wellington enter ready to resurrect the unabashed judicial activism of the glory days of the Warren Court."). 
be grasped by the people in ameliorating social and economic conditions." 54

Yet even in the early days of its use, the term was most often considered a slight. As now-judge Louis Pollak observed in 1956, "It seems safe to say that most judges regard 'judicial activism' as an alien 'ism' to which their misguided brethren sometimes fall prey." "55 By the mid-I950s, the term had taken on a generally negative connotation, ${ }^{56}$ even if its specific meaning was hard to pin down.

\section{Early Scholarly Examination of Judicial Activism}

While most early articles discussing judicial activism merely mentioned it or devoted a few paragraphs to it, one scholar recognized that the idea itself was worth careful attention. Edward McWhinney, ${ }^{57}$ then a barrister-at-Iaw and Professor of Law at the University of Toronto, brought a comparative law perspective to the idea of judicial activism and helped turn it into a topic worthy of serious scholarship during the 1950s.

McWhinney wrote two articles devoted specifically to judicial activism. In the first, The Supreme Court and the Dilemma of Judicial Policy-Making, ${ }^{58}$ McWhinney seeks to "understand the philosophic conflicts in the United States Supreme Court" much as Schlesinger did nearly a decade earlier, by examining the "dilemma bequeathed to the Court" by Justice Holmes. ${ }^{59}$ McWhinney identifies Holmes's "two-sided" view of the judicial role. First, there is the "judicial self-restraint" concept ${ }^{60}$ Holmes

54. Note, Administrative Law: Judicial Review Denied Attorney General's Order for Removal of Enemy Alien, 34 CORNEL.L. L.Q. 425, 429 (1949).

55. Louis H. Pollak, Review: The Supreme Court in the American System of Government, 65 YALE L.J. 749, 752 n. 11 (1956).

56. Even defenses of expansive or dynamic approaches to constitutional interpretation are usually not couched in direct praise for the practice of judicial aetivism as such. See, e.g., Erwin Chemerinsky, The Rhetoric of Constitutional Law, $100 \mathrm{MICH}$. L. REv. 2008, 2019-20 (2002) ("Obviously, judicial activism can be good or bad."). Furthermore, even scholars that extol the virtues of judicial activism in some contexts concede that it generally carries a strongly negative connotation. See, e.g., id. at 2020 (" $[\mathrm{R}$ /hetoric, both popular and in judicial opinions, treats judicial activism as inherently bad and judicial restraint as always good."); Erwin Chemerinsky, Perspective on Justice, L.A. Times, May 18, 2000, at B11 (criticizing "Reagan and Bush justices" for engaging in "aggressive conservative judicial activism ....").

57. Over the course of his prolifie career, Professor McWhinney has taught at Heidelberg, Indiana, Madrid, McGill, the Hague Academy, the National University of Mexico, Simon Fraser University, and the Sorbonne, among many others. The author of more than forty books and hundreds of articles, McWhinney is a well-respected scholar in numerous fields, including political science and international law. He has acted as a legal consultant to the United Nations and Constitutional and International Law Adviser to several foreign governments, and served as a Member of the Permanent Court of Arbitration at The Hague. During the 1990 s, McWhinney was a Member of the Canadian Parliament for two terms.

58. Edward McWhinney, The Supreme Court and the Dilemma of Judicial Policy-Making, 39 MinN. L. REV. 837, 837 (1955).

59. Id.

60. Id. (quoting Lochner v. New York, I98 U.S. 45, 76 (I905) (Holmes, J., dissenting)). 
espouses in his famous dissent in Lochner v. New York ${ }^{61}$ which amounts to a "presumption of constitutionality" for legislation even if a judge personally does not care for it. ${ }^{62}$ Judicial self-restraint is at odds, though, with another component of Holmes' judicial philosophy: the "tradition of judicial activism, involving the notion that in certain areas of subject matter, notably the field of political and civil rights, the Court should look with a jealous eye on legislation cutting down or trenching on those rights." 63 Under this tradition, a "judicial presumption of invalidity (or unconstitutionality)" should arise for legislation involving such rights ${ }^{64}$ as exemplified by Holmes' opinions in free speech cases like Schenck $v$. United States. ${ }^{65}$

While not blind to the inherent problems of judicial restraint, ${ }^{66}$ McWhinney ultimately prefers it to what he defines as judicial activism. First, McWhinney states that "judicial review is not always a very efficient form of policy-making ...." Judges are well versed in the law but they are "manifestly not the best equipped" to translate "community values into constitutional policies ...." ${ }^{68}$ Second, the adversarial process and "case or controversy" requirements severely limit the efficacy of judicial activism. McWhinney quotes Justice Frankfurter:

A court is confined within the bounds of a particular record, and it cannot even shape the record. Only fragments of a social problem are seen through the narrow windows of a litigation. Had we innate or acquired understanding of a social problem in its entirety, we would not have at our disposal adequate means for constructive solution. ${ }^{69}$

61. 198 U.S. 45, 76 (1905) (The Court should uphold a legislative enactment, even if it seems illadvised, "unless it can be said that a rational and fair man necessarily would admit that the statute proposed would infringe fundamental principles as they have been understood by the traditions of our people and our law.").

62. McWhinney, supra note 58 , at 837 .

63. Id.

64. Id.

65. 249 U.S. 47, 52 (1919) (announcing "clear and present danger" test). Such a presumption is most often associated with footnote four of United States v. Carolene Prods. Co., 304 U.S. 144, 152 n.4 (1938).

66. McWhinney notes that judicial self-restraint, at least for Justice Frankfurter, "is predicated on the rule of reason-unless the Court can say that reasonable men could not possibly have passed the legislation in question, the Court irrespective of its own views on the legislation, must uphold it." McWhinney, supra note 58 , at 848 . But this has its own problems. Judicial self-restraint, he explains, "involves the resort to legal relativism," and "seems to run the risk of too frequently reducing to an unconscious and therefore (since the weighing of policy alternatives requisite to an informed decision is necessarily absent) rather inefficient form of policy-making." Id. at 850 .

67. Id. at 843 .

68. Id.

69. Id. at 844 (quoting Sherrer v. Sherrer, 334 U.S. 343, 365-66 (1948) (Frankfurter, J., dissenting)). 
McWhinney describes his third objection as "a limitation of prestige."70 The Court should "avoid taking sides in the political conflicts of the age," McWhinney asserts. ${ }^{71}$ Otherwise, it would risk being embroiled in an "undignified partisan controversy." happened with the Old Court majority before 1937," the Court could undermine its own legitimacy by "going down with a lost political cause."73 Finally, McWhinney notes the oft-cited objection that judicial activism undermines the principle of majority rule, imposing "the will of the 'nine old men' on the prime representatives of the people, the legislature." 74 Put in language Justice Holmes might use, "a people must make their own salvation and not expect it to be served up to them by the judges." 75

McWhinney's article is valuable legal scholarship. It revisits concepts already present in the literature and takes these insights a step further, building a reasoned argument against an activist approach to judging. It is a measured piece and an invitation to scholarly dialogue. If Schlesinger introduced the term to the public, McWhinney played a key role in bringing it into the academic mainstream.

Three years later, McWhinney revised his views on the topic in an article called The Great Debate: Activism and Self-Restraint and Current Dilemmas in Judicial Policy-Making. ${ }^{76}$ It advances a more sophisticated theory of judicial activism, ${ }^{77}$ suggesting that broad, abstract notions of activism and restraint are so oversimplified as to be practically useless. McWhinney came to see that "the dichotomous classification of judicial philosophies favored by American legal commentators in the late 1940's and early 1950's - judicial activism versus judicial restraint-may not be a

\footnotetext{
70. Id. at 845 .

71. Id.

72. Id.

73. Id.

74. Id.

75. Id. at 846 .

76. 33 N.Y.U. L. REv. 775 (1958). McWhinney also explores some of these themes in his book, Judicial REVIEW IN THE ENGLISH-SPEAKING WORLD 170-77 (1956).

77. The article also highlights McWhinney's willingness to reconsider his previously stated views. For example, he suggests that history alone cannot resolve current disagreements over the proper judicial role:

[T]he cases for and against judicial self-restraint and judicial activism must be validated today by something more than a showing of an unbroken chain of connection with Holmes. . . . One might, indeed, say that even in terms of historical truth, it is unfair to invoke Holmes to solve the problems of the present day.

Edward McWhinney, The Great Debate: Activism and Self-Restraint and Current Dilemmas in Judicial Policy-Making, 33 N.Y.U. L. REv. 775, 778 (1958).
} 
pure dichotomy at all." ${ }^{78} \mathrm{He}$ posits that it would be more helpful to think of these two categories as "different points on a continuum."79

In The Great Debate, McWhinney offers a rubric for theorizing about judicial activism. He argues that, by focusing on issues of "timing" and "technique," Court-watchers can formulate meaningful profiles of each Justice to describe when and how they employ judicial activism.

McWhinney understands that broad labels are blunt tools that cannot encompass a judge's entire jurisprudence: "An activist qua what?," he asks. "It is not even enough to speak of a 'civil libertarian' activist. A judicial attitude, such as Black's favoring the restriction of state action interfering with speech-press liberties, may be activist qua speech but passivist qua the protections of states-rights and local self-determination in a federal system." Court, a judge might be activist qua constitutional federalism and relatively passivist on social issues. ${ }^{81}$ McWhinney's key insight is that terms like "judicial activist" can be useful if they are employed with precision and explained in detail.

While this is undoubtedly an improvement over Schlesinger's vague usage of the term, McWhinney acknowledges that his approach is "clearly only the beginning of wisdom in the analysis of Supreme Court jurisprudence in the United States." 82 McWhinney analyzed, amended, and ultimately replaced a basic conception of judicial activism. His new approach laid the groundwork for future scholars, and stands as a valuablc, if unrecognized, early contribution to this difficult topic.

\section{E. First Judicial Use of "Judicial Activism": Judge Joseph C. Hutcheson, Jr.}

While the exact origins of the term "judicial activism" in legal scholarship are hard to pin down with certainty, there is no question that Joseph C. Hutcheson, Jr. was the first to use it in a judicial opinion. A hard but dedicated judge who "barely missed out on an appointment to the Supreme Court which went to Hugo Black," Judge Hutcheson's contributions to

78. Id. at 790 .

79. Id.

80. Id. at 786 .

81. See, e.g., John O. McGinnis, Reviving Tocqueville's America: The Rehnquist Court's Jurisprudence of Social Discovery, 90 CalıF. L. REv. 485 (2002); Jed Rubenfeld, The AntiAntidiscrimination Agenda, 111 YALE L.J. 1141 (2002); Christopher O. Schroeder, Causes of a Recent Turn in Constitutional Interpretation, 51 DukE L.J. 307 (2001). But see Thomas Merrill, The Making of a Second Rehnquist Court: A Preliminary Analysis, 47 Sr. Louis U. L.J. 569, 571 (2003) ("I am not persuaded that the Court's reeent behavior can be neatly subsumed under any single conceptual rubric.").

82. McWhinney, supra note 77 , at 794 .

83. Anne S. Emanuel, Forming the Historic Fifth Circuit: The Eisenhower Years, 6 TEx. F. ON C.L. \& C.R. 233, 234 (2002). 
legal scholarship and service on the bench are generally praiseworthy. ${ }^{84}$ However, he started an unfortunate tradition in legal opinion-writing that continues to this day.

Judge Hutcheson's tenure on the bench spanned over fifty years, from World War I to Vietnam. While his judicial philosophy evolved over time, some of the enormous societal and legal changes over these years proved too much for him. He was particularly infamous for his strong disapproval of the National Labor Relations Board. ${ }^{85}$ Although "not a segregationist per se," Hutcheson was hardly a strong proponent of civil rights cases like Brown v. Board of Education ${ }^{86}$ and generally "opposed desegregation as a social policy." 87 And while he later regretted it, Hutcheson "succeeded in side-tracking the appointment of [staunch desegregationist] J. Skelly Wright to the Fifth Circuit." 88

Hutcheson authored the first recorded use of the term "judicial activism" in an opinion overruling a trial court decision by then-District Judge Skelly Wright. The case was Theriot $v$. Mercer, a "rather bizarre" action, "bolstered by an atmosphere of rumor and intrigue" that "took on [a] cloak and dagger aspect of political intrigue and scandal." Mr Mrs. Wanda Mercer originally brought a wrongful death suit against Paris Theriot for allegedly striking and killing Mercer's husband with his car. The only evidence to support this was that the "decedent's body was found alongside the road on the day following the time when defendant's vehicle and other vehicles passed the place where he was later found. . ."92 After Judge Wright denied two motions for directed verdict, a jury found Theriot guilty. On appeal, Judge Hutcheson wrote for a unanimous panel that Mercer presented insufficient evidence to prove Theriot's guilt. He held that several reversible errors during the trial tainted the jury's verdict.

In the opinion's penultimate paragraph, Judge Hutcheson used a footnote to condemn a strain of Seventh Amendment jurisprudence discussed in a dissent in Galloway v. United States ${ }^{93}$ as a form of "judicial activism." In Galloway, the Supreme Court held that the directed verdict was

84. Judge John Minor Wisdom called Hutcheson an innovative, "stiff-necked defender[] of the Constitution [who] loved the law." John Minor Wisdom, In Memoriam: One of a Kind, 71 TEx. L. REv. 913, 913 (1993).

85. See Douglas J. Feeney-Gallagher, Battle on the Benches: The Wagner Act and the Federal Circuit Courts of Appeals, 1935-1942, 23 SEATtLE U. L. Rev. 503, 532-540 (2000).

86. 347 U.S. 483 (1954).

87. See Charles L. Zelden, The Judge Intuitive: The Life and Judicial Philosophy of Joseph C. Hutcheson, Jr., 39 S. TEX. L. REV. 905, 915-16 (1998).

88. John R. Brown, In Memoriam: Judge J. Skelly Wright, 57 GEo. WASH. L. REv. 1029, 1030 (1989)

89. 262 F.2d 754 (1959).

90. ld. at 758 n.3.

91. Id. at 757 .

92. Id. at 755 n.l.

93. 319 U.S. 372 (1943). 
constitutional because the Seventh Amendment "was designed to preserve the basic institution of jury trial in only its most fundamental elements, not the great mass of procedural forms and details." 94 In that case, Justice Black penned a famous dissent, lamenting the declining role of juries and arguing that trial judges should only be able to order new trials. ${ }^{95}$ In Theriot, neither party questioned the judge's authority to direct a verdict, and Judge Hutcheson admitted that there was no need to comment on the Galloway debate. ${ }^{96}$ Nevertheless, he wrote:

We think, however, we should say that in the controversy thus launched and still continuing, we stand firm against the judicial activism back of the struggle and the results it seeks to achieve, and, regarding as we do the guaranties of the Seventh Amendment, as applicable to plaintiff and defendant alike, we cannot understand how protagonists for the change can look upon the amendment, as apparently they do, as intended for the benefit of plaintiffs alone and, so regarding it, as the dissenters in the Galloway case apparently did, advocate doing away with or limiting, beyond the ancient use, the control and guidance of the trial by an informed and experienced judge. ${ }^{97}$

This footnote is certainly dicta. It accuses three Supreme Court Justices (Black, Douglas, and Murphy) of being activists, ${ }^{98}$ yet it contains no specific argument against their position other than an accusation that they are trying to change "ancient landmarks." contain any citations directing the reader to cases or scholarship in support of Hutcheson's position. Scholars have written that Justice Black's views on the Seventh Amendment "have ample logic in their support" the dissent is based on a "version of historical events [that] has been widely accepted."101 Justice Black's dissent has not carried the day, but his interpretation of the Seventh Amendment is commendable for its grounding in historical, legal, logical, and policy-related arguments. Judge Hutcheson may have meant that Justice Black's position on the Seventh Amendment was ahistorical, bad policy, or that it fell short on some other ground. Yet Judge Hutcheson neither makes such a point, nor does the footnote itself

\footnotetext{
94. Id. at 392 .

95. Id. at 396-407, 411 (Black, J., dissenting).

96. Theriot, 262 F.2d at 760 n.5.

97. Id.

98. Id. ("[B]eginning with the disscnt of the activists in the Galloway case ....")

99. Id. Hutcheson does suggest that the judge plays a role in "controlling" and "guiding" the jury, but the suggestion is vague and not fleshed out. Id.

100. Jeffrey W. Stempel, A Distorted Mirror: The Supreme Court's Shimmering View of Summary Judgment, Directed Verdict, and the Adjudication Process, 49 Oнго ST. L.J., 95, 164 n.355 (1988).

101. Ann Woolhandler \& Michael G. Collins, The Article III Jury, 87 VA. L. Rev. 587, 625 (2001).
} 
add anything new or constructive to this debate. His use of the term "judicial activism" is more akin to name-calling than reasoned argument.

This use of "judicial activism" stands in contrast to the work of Schlesinger and McWhinney. In hindsight, these two scholars may have used the term somewhat imprecisely, but they used it to exchange ideas in a constructive manner. Judge Hutcheson's parting shot in Theriot is not an invitation to reasoned debate. Admittedly, judicial opinions are not essays or abstract legal scholarship; but this use of "judicial activism" is simply unilluminating.

Months later, Judge Hutcheson used the term once again, this time in a one-paragraph concurrence. In Refinery Employees Union of Lake Charles Area v. Continental Oil Co., Judge Wisdom held that judges, rather than arbitrators, have the power to determine the scope of the arbitrability of issues enumerated in arbitration clauses. ${ }^{102}$ He essentially limited the power of arbitrators to unilaterally determine whether ambiguous or unspecified issues are arbitrable.

Judge John R. Brown argued in his dissent that Judge Wisdom's opinion "is the same old effort to sugar-coat what, to the judiciary, has long been a bitter pill--the idea that someone other than a court can properly adjudicate disputes; that in the field of human disputes lawyers and exlawyers as judges alone have the Keys to the Kingdom."103 Judge Brown supported this contention by questioning the majority's reliance on precedent, looking to the consequences of its decision, and disagreeing with the majority's implicit policy preferences.

Judge Hutcheson issued this concurrence, defending the majority opinion:

Deprecating the ebullient enthusiasm of my younger brother as pioneer, teacher and guide in the role of judicial activist, which he seems to have assumed, I venture to suggest to him that before taking too seriously his role of leader in our court of an activist movement to deride and destroy the ancient landmarks of the law, he take a little time off to read and reflect upon these words from one of the great English legal historians:

'Philosophical speculation about law and politics is an attractive pursuit. A small knowledge of the rules of law, a sympathy with hardships which have been observed and a little ingenuity, are sufficient to make a very pretty theory. It is a harder task to become a master of Anglo-American law by using the history of that law to discover the principles which underlie its rules, and to elucidate the manner in which these principles have been developed and adapted to meet the infinite complexities of life in different ages. Such students of our law will learn even though at second hand,

102. 268 F.2d 447, 451-53 (1959).

103. Id. at 460 (Brown, J., dissenting). 
something of the practical wisdom which comes from knowledge of affairs. They will for that reason be able to suggest solutions of present problems which will depend not merely on their own unaided genius, but on the accumulated wisdom of the past. ${ }^{104}$

This opinion again exemplifies the use of "judicial activism" without a clear definition. As in Theriot, Judge Hutcheson provides no reasoned arguments to refute the position he criticizes. Judge Brown utilizes many of the classic tools of legal argument, looking to the text of the agreement itself, seeking to distinguish the precedent the majority relies on, and advancing policy arguments. Meanwhile, if Judge Hutcheson has a definition for "judicial activist" in mind for this concurrence, he keeps it to himself. As in Theriot, he refers to "ancient landmarks" of the law, likely indicating a historical or precedent-based argument. But even a careful reader cannot discern how the relevant history or precedent (whatever it might be) should have affected Judge Brown's reasoning or changed his result. At best, this usage of "judicial activism" is ambiguous; in all likelihood, it appears to be a form of name-calling, a barely camouflaged way of saying "judge with whom I disagree."

\section{F. Other Noteworthy Discussions of "Judicial Activism" in Judicial Opinions}

Judge Hutcheson's opinions were the first to mention "judicial activism," 105 but though many judges have invoked the term since, few have examined it with any thoroughness. Of all federal opinions mentioning "judicial activism," a mere eight of them use the term three times or more, ${ }^{106}$ while 227 cases mention it only once. Although this is not a perfect proxy for the quality of discussion, it suggests the frequency with which judges tend to label a view as activism without elaborating.

Some of the opinions that linger on the idea of judicial activism are noteworthy in their own right. One extraordinary exchange takes place in the 1978 Second Circuit decision, Turpin v. Mailet ${ }^{107}$ which holds that cities may be held liable in damages for violations of the Fourteenth

104. Id. at 460 (Hutcheson, J., concurring).

105. Through the year 2003, 264 federal and 364 state cases have invoked the term. Westlaw search ["judicial activist" judicial activism" "judicial activists" \& DA(BEF 1/1/2004)] in "ALLFEDS" and "ALLSTATES" databases, respectively, performed by author on August 19, 2004. In federal cases, after appearing only twice in the 1950s and four times in the 1960s, the term appeared in 24 opinions in the $1970 \mathrm{~s}, 87$ in the $1980 \mathrm{~s}, 108$ in the $1990 \mathrm{~s}$, and 39 more times in 2000-03. In state cases, since its first appearance in Scholle v. Secretary of State, 116 N.W.2d 350, 387 (Mich. 1962) (concurring opinion), "judicial activism" has appeared 10 times in the 1960s, 37 times in the 1970s, 109 times in the 1980s, 154 times in the 1990s, and 54 times in 2000-03. Series of searches performed by author on Lexis and Westlaw on Jan. 20, 2003 and Aug. 19, 2004.

106. Lexis search [atleast3 ("judicial activism" or "judicial activist" or "judicial activists" and date(geq (1/1/1940) and leq(12/31/2003))] performed by author on Aug. 19, 2004.

107. 579 F.2d 152 (2d Cir. 1978). 
Amendment. ${ }^{108}$ The case sounds much like Schlesinger's hypothetical dialogue between the Champions of Self Restraint and the Judicial Activists. A sharp dissent criticizes the majority for its conception of the judicial role.

The majority justify their holding by stating that they are simply creating a "[structure] for enforcement similar to those normally fashioned by legislatures." They say that they are "[invigorating] the political process," that they are indulging in "judicial rule-making" which they liken to "legislative activity," and that they are thus opening a "dialogue with Congress." 109

This critique is grounded in the separation of powers, and an understanding of the role of Article III courts. The dissent argues that the majority has stepped beyond its constitutional bounds by adopting the function of a legislature. This argument would resonate with the Frankfurterian Champions of Judicial Restraint, as Schlesinger portrayed them.

In defense of its claim that the majority's position is inappropriate, the dissent undertakes a brief reexamination of "the role that the federal judiciary was designed to play in our democratic society."110 Citing Blackstone's Commentaries, a seventeenth century English case, a constitutional law textbook, and other diverse sources, the dissent argues that "the judiciary was to be precluded from participating in the legislative process." "III It then declares:

One need only skim through the all too numerous Supreme Court dissents to recognize that on occasion judicial activism has been checked with a very loose rein. Sometimes this has pleased the so-called conservatives; at other times it has gratified the so-called liberals. During the early decades of the twenticth century, those who are today's staunchest supporters of judicial activism were the most vocal critics of the Supreme Court's "usurpation" of congressional powers in striking down social and welfare legislation. When the focus of the judiciary swung from property rights to personal rights, a new and different set of critics came to the fore. The issue, as these critics see it, is not one of liberalism versus conservatism, but one of representative democratic government versus judicial autocracy. ${ }^{112}$

Expressing strong disapproval for "constitutional common law," "113 which it sees as thinly veiled judicial legislation, ${ }^{114}$ the dissent sees this case as an example of improper use of the judicial role.

108. Id. at 154 .

109. Id. at $171-72$ (Van Graafeiland, J., dissenting).

110. Id. at 172 (Van Graafeiland, J., dissenting).

111. Id. at 173 (Van Graafeiland, J., dissenting).

112. Id. (Van Graafeiland, J., dissenting).

113. Id. at 173-74 (Van Graafeiland, J., dissenting) (citing Henry P. Monaghan, The Supreme Court 1974 Term Foreword: Constitutional Common Law, 89 HARv. L. Rev. 1 (1975)).

114. Id. at 174 (Van Graafeiland, J., dissenting). 
An equally vehement (if more civil) concurrence attempts to refute several points raised by the dissent, and concludes:

[T]he dissent emphasizes that "[j]udges should consider the economic and social consequences of their decisions and should gauge the wisdom of their acts by the results which are likely to ensue." ... I agree wholeheartedly. Of course, by this the dissent admits that value judgments do ultimately, and especially in hard cases, play a role, even in constitutional adjudication. I wonder how that admission squares with the dissent's purported eschewing of "judicial activism," "judicial legislation" and "judicial autocracy." In the end, it is the dissent's value judgment based upon "economic and social consequences" including "incalculable liability" that prompts the dissent to decide as it does. Different value judgments motivate the majority to decide a different way. I believe the dissent is entitled to its judgment without pejoratives. I regret that the dissent does not play by the same rules. ${ }^{115}$

The majority takes its cue from the Black-Douglas side of the debate in Schlesinger's article. It points out that policy judgments are inherently part of legal decisions, and therefore that judges ought to choose the result that makes the most sense.

Although the majority sees the dissent's charge of "judicial activism" as essentially a pejorative, the exchange in Turpin moves beyond mere name-calling. The dissent makes a reasoned argument from diverse authorities, explaining why the majority should have left the decision in the case to democratically elected and accountable legislatures. The majority responds by finding common ground and explaining that each side's approach is not much different from the other's. Despite the heated nature of the exchange, these opinions are encouraging examples of debate over "judicial activism" from the United States Reports.

A 1999 Fourth Circuit concurrence by Chief Judge J. Harvie Wilkinson III adopts and expands upon many of the themes discussed in Turpin. The case, Brzonkala v. Virginia Polytechnic Institute and State University, ${ }^{116}$ invalidated a portion of the Violence Against Women Act as exceeding "Congress'[s] power under both the Commerce Clause of Article I, Section 8, and the Enforcement Clause of Section 5 of the Fourteenth Amendment." 117 Judge Wilkinson concurs, ${ }^{118}$ admitting that "it is a grave judicial act to nullify a product of the democratic process," 119 but concludes that this case merits such an act.

115. Id. at 171 (Oakes, J., concurring) (footnotes omitted).

116. 169 F.3d 820 (4th Cir. 1999), aff d sub nom. United States v. Morrison, 529 U.S. 598 (2000).

117. Id. at 826 .

118. Id. at 889 (Wilkinson, C.J., concurring).

119. Id. at 890 (Wilkinson, C.J., concurring). 
Judge Wilkinson's concurrence suggests that judicial activism is alive and well in the United States. In the twentieth century, he explains, it "falls into three general stages." 120 The first stage was the Lochner era, "beginning roughly with the decision in Lochner $v$. New York, ${ }^{121}$ and continuing through the early New Deal," which "is still widely disparaged for its mobilization of personal judicial preference in opposition to state and federal social welfare legislation." 122 The second stage took place during the "Warren and Early Burger Courts," roughly the 1950s through the early 1970s, which "focused on finding new substantive rights in the Constitution and down played that document's structural mandates." 123 As Judge Wilkinson sees it, "Although many of its individual decisions were overdue and salutary, when the era is considered as a whole, the states were relegated to a second-class constitutional status." 124 Finally, the third stage of judicial activism "probably began with New York v. United States," 125 and continues into the twenty-first century. ${ }^{126}$

"The common thread of contemporary activism," Judge Wilkinson explains, "is an interest in reviving the structural guarantees of dual sovereignty." 127 The specific examples of this federalism revival are familiar to any observer of the Rehnquist Court, and have generated a great deal of commentary. They include cases limiting Congress's power under the Commerce Clause, ${ }^{128}$ cases restricting the ability of one branch of government to "commandeer" the instrumentalities of another, ${ }^{129}$ cases cabining Congress's "enforcement power" under section five of the Fourteenth Amendment, ${ }^{130}$ and an array of cases expanding or affirming the scope of the Eleventh Amendment. ${ }^{131}$

In Brzonkala and elsewhere, Judge Wilkinson uses this historical analysis of judicial activism to defend the Rehnquist Court's "New

\footnotetext{
120. Id. (Wilkinson, C.J., concurring).

121. 198 U.S. 45 (1905).

122. Brzonkala, 169 F.3d at 890 (Wilkinson, C.J., concurring).

123. Id. at 892 (Wilkinson, C.J., concurring).

124. Id. (Wilkinson, C.J., concurring).

125. 505 U.S. 144 (1992).

126. Brzonkala, 169 F.3d at 892 (Wilkinson, C.J., concurring).

127. Id. at 893 (Wilkinson, C.J., concurring).

128. See Morrison v. United States, 529 U.S. 598 (2000); United States v. Lopez, 514 U.S. 549 (1995).

129. See Printz v. United States, 521 U.S. 898 (1997); New York v. United States, 505 U.S. 144 (1992).

130. See Bd. of Trs. v. Garrett, 531 U.S. 356 (2001); Kimel v. Fla. Bd. of Regents, 528 U.S. 62 (2000); City of Boerne v. Flores, 521 U.S. 507 (1997)

131. See, e.g., Fed. Mar. Comm'n v. S.C. State Ports Auth., 535 U.S. 743 (2002) (holding that states are immune from private suits before formal administrative tribunals); Alden v. Maine, 576 U.S. 706 (1999) (holding that states are immune from private suits in state courts based on federal causes of action); Seminole Tribe of Fla. v. Florida, 517 U.S. 44 (1996) (holding that Congress cannot abrogate States' sovereign immunity by passing laws under the Commerce Clause).
} 
Federalism" cases. ${ }^{132}$ He points out that federalism is an important constitutional value, one that had been forgotten during the second stage of judicial activism, where "the doctrine of dual sovereignty had precious little place." ${ }^{133} \mathrm{He}$ argues that the third stage of judicial activism "is not a plunge off the constitutional cliff," but rather "a modest and necessary corrective," in which the Court approaches cases as "a structural referee, not an ideological combatant." 134 It does not pose any threat to the "binding effect of the Bill of Rights upon the states, or to the constitutional underpinnings of our most basic national civil rights statutes." 135 This analysis of judicial activism as an historical concept is commendable, whether or not one agrees with Wilkinson's ultimate conclusion, because it employs reasoned, civil argument in order to advocate for a position. It invites constructive dialogue about the Rehnquist Court's place in history, and the nature and justification of its "New Federalism" cases.

Turpin and Brzonkala illustrate that the concept of judicial activism can prompt discussion of important jurisprudential issues. But if speakers fail to define their terms with precision, initially promising exchanges may lack depth and clarity. The second half of this Comment seeks to reduce potential confusion by enumerating five definitions of "judicial activism" that appear in scholarly discussions and Supreme Court opinions. The Comment also alerts readers to subsidiary questions that arise when one carefully considers each definition.

\section{II}

\section{Definitions of Judicial ACTIVISM}

\section{A. Striking Down Arguably Constitutional Actions of Other Branches}

Legal academics often describe judicial invalidation of legislative enactment as "judicial activism." As one scholar has written, "At the broadest level, judicial activism is any occasion where a court intervenes and strikes down a piece of duly enacted legislation." 136 Cass Sunstein appears to have endorsed this view, penning an editorial in the New York Times that claims, "Conservative courts that embrace judicial activism will be just as likely to strike down legislation that has received bipartisan approval as legislation supported by liberals." ${ }^{137} \mathrm{He}$ supports this assertion by pointing, as

132. See id. at 893-898; see generally J. Harvie Wilkinson 11l, Federalism for the Future, $74 \mathrm{~S}$. CAL. L. REv. 523 (2001); J. Harvie Wilkinson IIl, Is There a Distinctive Conservative Jurisprudence?, 73 U. COLO. L. REV. 1383 (2002).

133. Wilkinson III, Is There a Distinctive Conservative Jurisprudence?, supra note 132, at 1391 .

I34. Id. at 1391-92, 1387

135. Id. at 1391 .

136. Greg Jones, Proper Judicial Activism, 14 Regent U. L. REv. 141, 143 (2002).

137. Cass R. Sunstein, Editorial, Taking Over the Courts, N.Y. TıMEs, Nov. 9, 2002, at A19. For further commentary on this editorial, see the Nov. 9, 2002, blog post entitled, "Sunstein Axes "Judieial 
Court-watchers often do, ${ }^{138}$ to the number of state and federal laws the Court has recently invalidated. ${ }^{139}$

Invalidation alone, however, reveals little about the propriety of individual decisions. The mere fact that the Court has struck down more laws in recent years does not automatically render the individual decisions suspect. ${ }^{140}$ Imagine, for example, that Congress somehow passed a bipartisan statute that established a national religion. If the Court invalidated this clearly unconstitutional law, no one would suggest that it had engaged in judicial activism. "Judicial activism" cannot be synonymous with merely exercising judicial review. ${ }^{141}$

Sunstein recognizes the need for a more limiting principle and refines his definition to include only the invalidation of statutes that are arguably constitutional. He notes that "the Constitution contains ambiguities," and "[r]easonable people have opposed campaign finance regulation, gun control, affirmative action and restrictions on advertising. But it is a stretch to think that the Constitution, fairly interpreted, opposes all of these things, too." 142 Thus, Sunstein's view is actually close to the definition provided by Professor Lino Graglia: "By judicial activism I mean, quite simply and specifically, the practice by judges of disallowing policy choices by other governmental officials or institutions that the Constitution does not clearly prohibit." 143 In other words, the Court is engaging in judicial activism when

Activism,' Accidentally Chops Off Toe..." at http://www.discriminations.us/storage/001552.html (last visited Sept. 19, 2004).

138. See, e.g., Ruth Colker \& Kevin M. Scott, Dissing States? Invalidation of State Action During the Rehnquist Era, 88 VA. L. REv. 1301, 1307-08 (2002); see also Ernest A. Young, Judicial Activism and Conservative Politics, 73 U. CoLo. L. REv. 1139, 1146 n.20 (2002) (listing other critics who have made this observation); Obstruction of Justice, NEw REPUBLIC, May 19, 1997, at 9 ("A recent study by the libertarian Institute for Justice confirms the absurdity of GOP charges that Clinton's Supreme Court nominees are avatars of judicial activism. Justices Ruth Bader Ginsburg and Stephen Breyer are more restrained and less likely to strike down federal and state laws involving economic and civil liberties than any of their Republican colleagues.").

139. Sunstein, supra note 137, at 19 ("Since 1995, the Supreme Court has struck down at least 26 acts of Congress on constitutional grounds.").

140. Indeed, it may suggest that the problem lies with Congress, not the Court. Justice Scalia, for one, has suggested that "Congress is increasingly abdicating its independent responsibility to be sure that it is being faithful to the Constitution." Stuart Taylor Jr., The Tipping Point, NAT'L J., June 10, 2000, at 1811. See also Neal Devins, Congress as Culprit: How Lawmakers Spurred on the Court's Anti-Congress Crusade, 51 DuKE L.J. 435, 442 (2001) ("Congress simply seems indifferent to the constitutionality of its enactments ....").

141. See Erwin Chemerinsky, The Price of Asking the Wrong Question: An Essay on Constitutional Scholarship and Judicial Review, 62 TEX. L. REV. 1207, 1207-10 (1984) ("1 contend that this inquiry into the legitimacy of judicial review is futile and dangerous.").

142. Sunstein, supra note 137 , at 19 .

143. Lino A. Graglia, It's Not Constitutionalism. It's Judicial Activism, 19 HARv. J.L. \& PuB. PoL'y 293, 296 (1996). 
it reaches beyond the clear mandates of the Constitution to restrict the handiwork of the other government branches. ${ }^{144}$

Like the Frankfurterian model portrayed by Schlesinger, this definition rests on respect for the separation of powers. Yet Professor Sunstein takes it in a markedly different direction, describing the Court's "New Federalism" jurisprudence as activist. ${ }^{145}$

Justice Souter, dissenting in United States v. Lopez, ${ }^{146}$ offered one version of this emergent criticism of judicial activism, arguing that the Court's "overriding [of] congressional policy choices under the Commerce Clause" has historically been unsuccessful for two reasons. ${ }^{147}$ " $[\mathrm{N}]$ othing in the Clause compelled the judicial activism, and nothing about the judiciary as an institution made it a superior source of policy on the subject Congress dealt with. There is no reason to expect the lesson would be different another time." 148 Under the Sunstein/Graglia definition, this is judicial activism, but only if one accepts Justice Souter's view that the Commerce Clause itself does not clearly prohibit the Gun-Free School Zones Act of 1990. As Professor Sunstein might say, the point is at least arguable, and since that is so, the Court is encroaching upon territory not clearly reserved to it.

One difficulty with this version of judicial activism is that it rests on a highly debatable conception of the role of the Supreme Court. Marbury $v$. Madison's famous dictum ${ }^{149}$ contains no proviso excepting all close or debatable cases. In fact, the Court might appear to be abdicating its duty to interpret the Constitution if it consistently punted on hard questions. While scholars such as Larry Kramer ${ }^{150}$ and Mark Tushnet ${ }^{151}$ argue that the Court should not be the final expositor of the Constitution for all branches of government, the vast majority of legal scholars ${ }^{152}$ argue with equal vehemence that the Constitution (as interpreted by Marbury) says what it

144. One observer has synthesized the Sunstein and Graglia definitions into the following statement: "Judicial activism involves invoking novel or debatable interpretations of the Constitution to strike down democratically adopted state or federal laws and practices that offend one's moral or political beliefs, while showing relatively little deference to the other branches of government and the voters." Taylor, supra note 140 , at 1818 .

145. See, e.g., Cass Sunstein, 2002 Senate Committee Hearings on the Judicial Nomination Process, 50 DRAKE L. REv. 429, 463 (2002) (suggesting that in the current era of "conservative judicial activism, ... the federal judiciary is showing too little respect for the prerogatives of Congress [and] an excessive willingness to intrude into democratic processes").

146. 514 U.S. 549 (1995).

147. Id. at 611 (Souter, J., dissenting).

148. Id. (Souter, J., dissenting).

149. 5 U.S. 137, 177 (1803) ("It is emphatically the province and duty of the judicial department to say what the law is.").

150. See, e.g., Larry D. Kramer, Foreword: We the Court, 115 Harv. L. Rev. 4 (2001); Larry D. Kramer, Putting the Politics Back into the Political Safeguards of Federalism, 100 CoLum. L. REv. 215 (2000).

151. See, e.g., Mark Tushnet, Taking the Constitution Away from the Courts (2000).

152. See Kramer, Foreword, supra note 150, at 5-9 and accompanying footnotes. 
appears to say: the Supreme Court can and should declare what the law is, even in difficult or politically sensitive cases.

This view of judicial activism has another, more practical flaw: the line between proper judicial review and judicial activism depends on the speaker's understanding of the Constitution. Recall that Professor Graglia's definition requires agreement on what the Constitution "does not clearly prohibit." 153 Thus, this definition of judicial activism depends on the speaker's view of whether the Constitution has expressly prohibited policy choices in any given area of the law - even relatively unsettled areas such as abortion, affirmative action, and the right to bear arms, to name a few. The subjective quality of this definition means that discussions of this kind of judicial activism will quickly evolve into debates over constitutional meaning. These discussions are worthwhile, to be sure, but they are unlikely to result in easy answers.

\section{B. Ignoring Precedent}

Judges regularly admonish their colleagues for judicial activism when they contravene precedent, but the concept is not as simple as it may first appear. When using "judicial activism" to describe the process of ignoring or disregarding precedent, two important distinctions must be made, both of which are related to the source of the precedent. One distinction depends on whether the precedent is vertical or horizontal, and the other depends on whether the precedent is a matter of constitutional, statutory, or common law.

\section{Vertical versus Horizontal Precedent}

Some instances of disregarding precedent are almost universally considered inappropriate. For example, in a rare showing of unity in a Supreme Court opinion discussing judicial activism, ${ }^{154}$ Justice Stevens wrote that a circuit court "engaged in an indefensible brand of judicial activism" when it "refused to follow" a "controlling precedent" of the Supreme Court. ${ }^{155}$ The rule that lower courts should abide by controlling precedent, sometimes called "vertical precedent,"156 can safely be called

153. See Graglia, supra note 143 , at 296.

154. Rodriguez de Quijas v. Shearson/Am. Exp., Inc., 490 U.S. 477 (1989) (interpreting the Securities Act of 1933).

155. Id. at 486 (Stevens, J., dissenting). This statement is unanimous because the four dissenters explicitly agreed with the majority's statement on this point. See id. at 484 . The majority, however, does not actually use the term "judicial activism."

156. See Steven G. Calabresi \& Gary Lawson, Equity and Hierarchy: Reflections on the Harris Execution, 102 YALE L.J. 255, 276 n.106(1992). 
settled law. ${ }^{157}$ It appears to be equally well accepted that the act of disregarding vertical precedent qualifies as one kind of judicial activism.

"Horizontal precedent," the doctrine requiring a court "to follow its own prior decisions in similar cases," 158 is a more complicated and debatable matter. Many judges have deemed activist the failure to adhere to horizontal precedent. ${ }^{159}$ For example, Justice Brennan, dissenting in Engle v. Issac, ${ }^{160}$ labeled the majority's treatment of a habeas corpus case a "conspicuous exercise in judicial activism-particularly so since it takes the form of disregard of precedent scarcely a month old."161 Likewise, a dissent by Justice Stevens in one of the Court's recent Eleventh Amendment cases mentions several reasons why he believes the majority in Kimel $v$. Florida Board of Regents to be mistaken. ${ }^{162}$ Chief among these is that, "by its own repeated overruling of earlier precedent, the majority has itself discounted the importance of stare decisis in this area of the Iaw."163 This "kind of judicial activism," Justice Stevens explains, is "such a radical departure from the proper role of this Court that it should be opposed whenever the opportunity arises." 164

Yet, academics argue that it is sometimes proper to disregard horizontal precedent. Professor Gary Lawson, for example, has argued that stare decisis itself may be unconstitutional if it requires the Court to adhere to an erroneous reading of the Constitution. ${ }^{165}$ "If the Constitution says $X$ and a prior judicial decision says $\mathrm{Y}$, a court has not merely the power, but the obligation, to prefer the Constitution." "66 In the same vein, Professors Ahkil Amar and Vikram Amar ${ }^{167}$ have stated, "Our general view is that the

157. See Hutto v. Davis, 454 U.S. 370, 375 (1982) (per curiam) ("[U]nless we wish anarchy to prevail within the federal judicial system, a precedent of this Court must be followed by the lower federal courts no matter how misguided the judges of those courts may think it to be."); see also Evan H. Caminker, Why Must Inferior Courts Obey Superior Court Precedents?, 46 Stan. L. Rev. 817 (1994).

158. Richard G. Kopf, An Essay on Precedent, Standing Bear, Partial-Birth Abortion and Word Games-A Response to Steve Grasz and Other Conservatives, 35 Creighton L. Rev. 11, 11-12 n.5 (2001).

159. The two examples (both dissents) used here invoke disregard of precedent as one of several reasons why the majority opinion represents judicial activism.

160. 456 U.S. 107 (1982).

161. Id. at 137 (Brennan, J., dissenting). One might argue that recently forged precedent should have less weight than well-settled rules, since it may not have existed long enough to change the public's reliance interests or to qualify as settled law.

162. Kimel v. Fla. Bd. of Regents, 528 U.S. $62,98-99$ (2000).

163. Id. at 98 (Stevens, J., dissenting).

164. Id. at $98-99$ (Stevens, J., dissenting).

165. See Gary Lawson, The Constitutional Case Against Precedent, 17 HARv. J.L. \& PuB. PoL'Y 23,24 (1994).

166. Id. at $27-28$.

167. Akhil Reed Amar \& Vikram David Amar, How Should the Supreme Court Weigh its Own Precedent?, F1NDLAW's WRIT, Dec. 13, 2002, at http://writ.news.findlaw.com/amar/20021213.html; Akhil Reed Amar \& Vikram David Amar, Precedent on the High Court, FindLaw's WriT, Dec. 27, 2002, at http://writ.news.findlaw.com/amar/20021227.html; Vikram David Amar, Some Final Thoughts 
Rehnquist Court's articulated theory of stare decisis tends to improperly elevate judicial doctrine over the Constitution itself. It does so, they argue, by requiring excessive deference to past decisions that themselves may have been misinterpretations of the law of the land." 168 For Lawson, Akhil Amar, and Vikram Amar, dismissing erroneous horizontal precedent would not be judicial activism; instead, it would be appropriate constitutional decisionmaking.

Courts agree with scholars that horizontal precedent can be disregarded in some instances as shown by the opinions in Planned Parenthood v. Casey ${ }^{169}$ and Lawrence v. Texas. ${ }^{170}$ The Court in Casey observes that "stare decisis is not an 'inexorable command"' and suggests a list of factors for when overruling constitutional precedents might be appropriate. ${ }^{171}$ Justice O'Connor's factors are helpful, but they seem to invite nearly as many questions as they answer. ${ }^{172}$ Casey also reveals deep divisions among the justices over how to treat constitutional precedents. ${ }^{173}$

Casey is further complicated by Lawrence v. Texas, ${ }^{174}$ where Justice Kennedy recasts the four-factor Casey test as a single inquiry into reliance interests. ${ }^{175}$ As Justice Scalia explains in his dissent, the Lawrence majority "do[es] not bother to distinguish-or indeed, even bother to mention-the paean to stare decisis coauthored by three Members of today's majority in

on the Affirmative Action Ruling, and Reliance in a Changing Legal World, FindLaw's WRIT, Jan. 10, 2003, at http://writ.news. findlaw.com/amar/20030110.html.

168. Amar, Some Final Thoughts, supra note 167, at 1. See also Akhil Reed Amar, The Supreme Court 1999 Term. Foreword: The Document and the Doctrine, 114 HARV. L. REv. 26 (2000).

169. 505 U.S. 833 (1992).

170. 539 U.S. $558(2003)$.

171. 505 U.S. at 854-55 (citations omitted). These factors are:

[W]hether [a precedent's] central rule has been found unworkable; whether the rule's limitation on state power could be removed without serious inequity to those who have relied upon it or significant damage to the stability of the society governed by it; whether the law's growth in the intervening years has left [the precedent's] central rule a doctrinal anachronism discounted by society; and whether [the precedent's] premises of fact have so far changed in the ensuing two decades as to render its central holding somehow irrelevant or unjustifiable in dealing with the issue it addressed.

Id. at 855 .

172. For example, was this part of Casey dicta? See id. at 954 (Rehnquist, C.J., concurring in the judgment in part and dissenting in part). There remains a real question as to whether it actually reconsidered and reaffirmed the basic holding of Roe v. Wade, 410 U.S. 113 (1973). Also, Justice O'Connor called the factors "examples" of how the court should consider overturning precedent; thus, they are certainly not an unbending test. Casey, 505 U.S. at 854.

173. Compare the plurality's test with that of Justice Scalia: "[T]he Justices should do what is legally right by asking two questions: (1) Was Roe correctly decided? (2) Has Roe succeeded in producing a settled body of law? If the answer to both questions is no, Roe should undoubtedly be overruled." Id. at 999.

174. 539 U.S. $558(2003)$.

175. Id. at 577 ("In Casey we noted that when a Court is asked to overrule a precedent recognizing a constitutional liberty interest, individual or societal reliance on the existence of that liberty cautions with particular strength against reversing course."). 
Planned Parenthood v. Casey." 176 Based on this recent fluctuation in the Court's doctrine regarding horizontal precedent, it seems the Court does not have a settled theory on the matter.

What, then, can one make of a claim that a decision represents judicial activism because it overrules horizontal precedent? Like the first definition of judicial activism described above, these charges rest on complex assumptions about the law that is overruled and the underlying constitutional provisions that may justify disregarding the precedent. Despite these difficulties, judges and scholars commonly identify disregard of horizontal precedent as judicial activism.

\section{Constitutional versus Statutory versus Common Law Precedents}

Charges of "judicial activism" as disregarding precedent must be considered in light of the fact that courts treat different kinds of law differently. As William Eskridge, Jr. has observed, the Supreme Court has created a "three-tiered hierarchy of stare decisis." 177

The Supreme Court affords deference to common law precedents because it feels that lower courts are in a better position to change the law. ${ }^{178}$ By contrast, lower courts-especially state courts-generally accept their role as caretakers of the common law, and are therefore willing to help it evolve over time. ${ }^{179}$ As one scholar has suggested, common law judges are "akin to lawmakers," and "overturning a case is not much different than a legislature repealing or mooting a statute with a subsequent statute."180

Constitutional law precedents, meanwhile, are entitled to less deference "because the difficulty of amending the Constitution makes the Court the only effective resort for changing obsolete constitutional doctrine."181 Even though reliance interests may counsel otherwise, ${ }^{182}$ constitutional decisions are given a relatively small amount of deference.

Statutory precedents, on the other hand, "often enjoy a super-strong presumption of correctness." ${ }^{83}$ Courts reason that once they construe a statute, their interpretation becomes part of the statute itself, so that "overruling the earlier opinion is almost like repealing and rewriting the

\footnotetext{
176. Id. at 587 (Scalia, J., dissenting).

177. William Eskridge, Jr., Overruling Statutory Precedents, 76 GEo. L.J. 1361, 1362 (1988)

178. See id. ("Common law precedents enjoy a strong presumption of correctness.").

179. See Brian C. Kalt, Three Levels of Stare Decisis: Distinguishing Common Law, Constitutional, and Statutory Cases, 8 TEx. REv. L. \& PoL. 277, 278 (2004).

180. Id.

181. Id.; see also Burnet v. Coronado Oil \& Gas, Co., 285 U.S. 383, 405 (1932) (Brandeis, J., dissenting) ("In cases involving the Federal Constitution, where correction through legislation is practically impossible, this court has often overruled its earlier decisions.").

182. See Burnet, 285 U.S. at 406 ("Stare decisis is usually the wise policy, because in most matters it is more important that the applicable rule of law be settled than that it be settled right.").

183. Eskridge, supra note 177, at 1362.
} 
statute, which is something that only the legislature is supposed to do."184 Though Professor Eskridge is critical of this approach, ${ }^{185}$ he acknowledges that it remains the prevailing wisdom. ${ }^{186}$

Thus, common law, constitutional, and statutory precedents are not treated the same. But the matter becomes further complicated because at times, both constitutional law and statutory provisions tend to look like common law. As Judge Posner explains, "Some statutes, indeed, are so general that they merely provide an initial impetus to the creation of frankly judge-made law (as in antitrust) ...."187 In these circumstances, a technically statutory provision becomes essentially a body of common law. "Furthermore," Judge Posner notes, "the decline of pure common law has been matched by the rise of a style of constitutional law that is ever less anchored in the constitutional text, and therefore ever more like common law."188 These developments mean that critics must adapt their analysis of different types of law based not only on what the law is, but how it functions.

These distinctions between type and function of law gave rise to a disagreement in Alexander $v$. Sandoval, ${ }^{189}$ which involved a dispute over whether individuals have a private right of action to sue to enforce disparate impact regulations promulgated under Title VI of the Civil Rights Act of 1964. ${ }^{190}$ Justice Scalia argued for the majority that a purpose-based judicial search for a private right of action represented a style of reasoning more appropriate for common law cases. ${ }^{191}$ In his dissent, Justice Stevens took issue with this characterization. "As the majority narrates our implied right of action jurisprudence, the Court's shift to a more skeptical approach represents the rejection of a common-law judicial activism in favor of a principled recognition of the limited role of a contemporary 'federal tribunal." "192 Justice Stevens argued that he, rather than the majority, was being faithful to Congress's intent. ${ }^{193}$ Nevertheless, at least from the

184. Kalt, supra note 179 , at 279.

185. The "super-strong presumption against overruling statutory precedents," Professor Eskridge argues, "is a very odd doctrine, if it can even be called that. lts exact origins are something of a mystery, its precedential support is shaky, and its uneven development and application have spawned a dizzying array of exceptions." Eskridge, supra note 177 at 1364-65, 1392.

186. Id. at 1364-69.

187. Richard A. Posner, The Meaning of Judicial Self-Restraint, 59 IND. L.J. 1, 5-6 (1984).

188. Id.; see also Henry P. Monaghan, Foreword: Constitutional Common Law, 89 HARv. L. Rev.

1,3 (1975) (offering "a principled basis for a specialized common law rooted in the Constitution.").

189. 532 U.S. $275(2001)$.

190. 42 U.S.C. $\$ 2000 d$ et seq.

191. Sandoval, 532 U.S. at 287 ("Raising up causes of action where a statute has not created them may be a proper function for common-law courts, but not for federal tribunals.") (quoting Lampf, Pleva, Lipkind, Prupis \& Petigrow v. Gilbertson, 501 U.S. 350, 365 (1991)).

192. Id. at 311 (citations and internal quotations omitted) (Stevens, J., dissenting).

193. See id. (Stevens, J., dissenting). 
majority's perspective, the Court could not agree on the proper style of judicial reasoning to apply to the statutory scheme.

These examples suggest that even one of the most uncontroversial definitions of judicial activism requires reaching deeper into jurisprudential concepts than one might first expect. Adherence to precedent is surely a virtue in most cases, but it is helpful to tease out precisely which kind of precedent-and what kind of law-is at issue. Only then can one make a constructive point about "judicial activism" as disregarding precedent.

\section{Judicial Legislation}

Judges are labeled judicial activists when they "legislate from the bench." President George W. Bush has invoked this meaning, saying that he plans "to appoint strict constructionists who would hew closely to the law rather than judicial activists whom he said were prone to 'legislate from the bench.' 'We want people to interpret the law, not try to make law and write law,' he said."194

This usage has also surfaced in several Supreme Court opinions. In Florida $v$. Wells, ${ }^{195}$ a case involving the Fourth Amendment, Justice Stevens wrote in dissent, "It is a proper part of the judicial function to make law as a necessary by-product of the process of deciding actual cases and controversies. But to reach out so blatantly and unnecessarily to make new law in a case of this kind is unabashed judicial activism." 196

Justice Douglas expressed a similar sentiment in a 1974 copyright case. ${ }^{197}$ There, the majority found that defendants who intercepted broadcast transmissions of copyrighted material and sent the content to paying subscribers were not guilty of copyright infringement. Justice Douglas began his dissent by writing, "The Court today makes an extraordinary excursion into the legislative field." 198 The majority's result, he believed, "may or may not be desirable public policy. But it is a legislative decision that not even a rampant judicial activism should entertain." 199 Justice Douglas's objection to the Court's decision is rooted in the separation of powers. He feels that the judiciary should not perform a role assigned to the legislature. $^{200}$

\footnotetext{
194. Bush: No Moderate Judges, NEWSDAY, Mar. 29, 2002, at A16, available at 2002 WL 2735564.

195. 495 U.S. 1 (1990).

196. Id. at 13 (Stevens, J., dissenting).

197. Teleprompter Corp. v. CBS, Inc., 415 U.S. 394 (1974) (superseded by statute).

198. Id. at 416 (Douglas, J., dissenting).

199. Id. at 419 (Douglas, J., dissenting).

200. Cf. Griswold v. Connecticut, 381 U.S. 479, 527 (1965) (Stewart, J., dissenting) (expressing analogous concerns about invalidating an "uncommonly silly" law forbidding the use of contraceptives).
} 
Justice Powell used the term in a similar manner in the school desegregation case Columbus Board of Education v. Penick. ${ }^{201}$ He admitted that "there is reason to believe that some legislative bodies have welcomed judicial activism with respect to a subject so inherently difficult and so politically sensitive that the prospect of others confronting it seems inviting." ${ }^{202}$ Nevertheless, he argued, "[t]he time has come for a thoughtful re-examination of the proper limits of the role of courts in confronting the intractable problems of public education in our complex society." 203 Justice Powell was troubled by the institutional difficulties that accompany judicial supervision and enforcement of "wide-ranging decrees." $204 \mathrm{He}$ expressed concern that "[l]ocal and state legislative and administrative authorities," which are better designed and equipped to handle such issues, "ha[d] been supplanted or relegated to initiative-stifling roles as minions of the courts." 205

Justice Powell essentially saw the courts as doing the work of local and state legislatures. While recognizing that this may be convenient and salutary in some circumstances, he concluded with one of the most forceful arguments against this form of judicial activism. "Courts are the branch least competent to provide long-range solutions acceptable to the public and most conducive to achieving both diversity in the classroom and quality education." ${ }^{206}$ In short, courts are less competent policy-making bodies than the legislature. ${ }^{207}$

Some criticisms of the Warren Court's jurisprudence as "judicial activism" amount to a concern that it is a form of judicial legislation. Justice Black expressed this view in dissent in United States v. Wade ${ }^{208}$ a case about the right to counsel during a post-indictment lineup. Justice Black argued that the Court's proposed remedy-a new trial unless the government could show that introducing the evidence was harmless error-was far too strong. In the first-ever Supreme Court use of the term "judicial activism," Justice Black wrote that if he followed the majority, he "would feel that we are deciding what the Constitution is, not from what it says, but from what we think it would have been wise for the Framers to put in it. That to me would be 'judicial activism' at its worst." 209 From Justice Black's perspective, the majority was acting as a mini-legislature

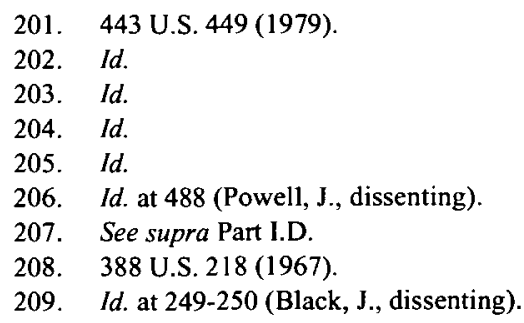


by reading rights into the Due Process Clause where he believed they did not exist.

Critics of the Warren Court have often voiced Justice Black's concerns. ${ }^{210}$ Even admirers of the Warren Court concede that it was activist in this sense. As Gary Schwartz put it, "In its constitutional rulings, the Warren Court was the paradigm of judicial activism."211 However, many of the Warren Court decisions most often labeled as judicial activism have gained acceptance. For example, Miranda $v$. Arizona,${ }^{212}$ which created a mandatory warning that police must give to all suspects upon arrest, ${ }^{213}$ is generally accepted by the public and the police, ${ }^{214}$ a fact cited in its reaffirmation by the Supreme Court itself in United States $v$. Dickerson. ${ }^{215}$

Cases like Miranda serve as reminders that whether a case is "activist" may not explain whether or not it is a good decision, when one's definition of "good" is based on other criteria. Individual cases can result in favorable consequences or set desirable precedents despite being improper exercises of the judicial function. Thus, one problem with using "judicial activism" as a pejorative, as critics of the Warren Court often do, is that it confuses the issues. Using "activist" as a substitute for "bad" elides important differences between the two labels; it fails to elucidate the specific ways in which a judicial opinion is improper, harmful, or wrong.

\section{Departures from Accepted Interpretive Methodology}

While canons of interpretation have long been criticized as unhelpful or conclusory, ${ }^{216}$ the failure to use the "tools" of the trade appropriatelyor not at all-can be labeled "judicial activism."217 Accusations of this form of judicial activism are common, but divergences of opinion over what constitutes an appropriate interpretative tool make it difficult to

210. See, e.g., Ronald J. Krotoszynski, Jr., A Rememberance of Things Past? Reflections on the Warren Court and the Struggle for Civil Rights, 59 WASH. \& LEE L. REv. 1055, 1072 (2002) (referencing "the commonly held view that the Warren Court was, in fact, too activist."); Gerald Walpin, Take Obstructionism Out of the Judicial Nominations Confirmation Process, 8 TEx. REv. L. \& PoL. 89, 108-09 (2003) (Chief Justice Warren "is now viewed as having carved out a powerful position for the Court as a protector of civil rights by creating the 'judicial activist' Warren Court.").

211. Gary T. Schwartz, The Beginning and the Possible End of the Rise of Modern American Tort Law, 26 GA. L. REv. 601, 609 (1992).

212. 384 U.S. $436(1966)$.

213. Id. at 471 .

214. See, e.g., William S. Consovoy, The Rehnquist Court and the End of Constitutional Stare Decisis: Casey, Dickerson, and the Consequences of Pragmatic Adjudication, 2002 UTAH L. REv. 53, $98 \mathrm{n} .271$ (2002) (noting "the public's support for the [Miranda] warnings ....").

215. 430 U.S. 428,443 (2000) ("Miranda has become embedded in routine police practice to the point where the warnings have become part of our national culture.").

216. See, e.g., Karl N. Llewellyn, Remarks on the Theory of Appellate Decision and the Rules or Canons about How Statutes Are to Be Construed, 3 VAND. L. Rev. 395, 401-06 (1950).

217. Again, the distinction between constitutional, statutory, and common law cases should be stressed here, since different canons of interpretations can apply in each context. 
distinguish principled but unorthodox methodologies from "activist" interpretation.

Consider a hypothetical constitutional case. An originalist like Justice Thomas ${ }^{218}$ might begin and end with a single question: Was the practice in question acceptable at the time the constitutional provision was ratified? Justice Scalia employs a variant of this approach. He has defined judicial activism as "including 'decisions that hold unconstitutional practices that were not only approved at the founding but that were continuously viewed as constitutional by at least a substantial portion of the American people,' down to the present day."219 In contrast, a more pragmatic judge like Justice Breyer might appeal to a broader range of interpretive tools in a constitutional dispute. ${ }^{220}$ Akhil Reed Amar has suggested that the "basic building blocks of conventional constitutional argument" 221 include "[t]ext, history, structure, prudence, and doctrine." 222 Conceivably, a more pragmatic Justice might deem "activist" any constitutional decision made without careful consideration of these forms of argument. The difficulty is immediately apparent. Although there is some baseline of consensus, scholars and jurists do not agree on what constitutes the "appropriate" way to interpret the Constitution. Accordingly, they will remain in disagreement over a charge of judicial activism in this context. ${ }^{223}$

The difficulty in applying established canons of interpretation is evident in non-constitutional cases as well. For example, in statutory interpretation cases, textualists ${ }^{224}$ might be deemed judicial activists for refusing to consider legislative history or statutory purpose. Justice Stevens expressed this sort of dissatisfaction with his colleagues in Wards Cove Packing Co., Inc. $v$. Atonio, ${ }^{225}$ an employment discrimination case. In his dissent, he wrote, "[t]urning a blind eye to the meaning and purpose of Title VII, the

218. See generally Scott Douglas Gerber, First Principles: The Jurisprudence of Clarence Thomas (1999) (describing Justice Thomas's brand of originalism).

219. Taylor, supra note 140 , at 1816.

220. Henry P. Monaghan, Doing Originalism, 104 CoLum. L. Rev. 32, 35 (2004) (referring to Justice Breyer as a "present-centered pragmatist, a problem solver, an all-things-considered Justice . . .); Richard J. Pierce, Jr., Justice Breyer: Intentionalist, Pragmatist, and Empiricist, 8 AdmIN. L.J. AM. U. 747 (1995).

221. Akhil Reed Amar, Intratextualism, 112 HaRv. L. Rev. 747, 754 (1999).

222. Id. at 754; see generally id. at 750-755. Amar adds two additional kinds of arguments: "ethical argument" and "intratextualism." Id. at 754 ("By 'ethical,' Bobbitt has in mind not an argument from morality pure and simple, but an argument from the cthos, or character, of the American people and the American experience.") (citing Phillip Bobbitt, Constitutional Fate: Theory of THE ConSTITUTION 93-119 (1982)); id. at 748-749 ("In deploying [intratextualism], the interpreter tries to read a contested word or phrase that appears in the Constitution in light of another passage in the Constitution featuring the same (or a very similar) word or phrase.").

223. See generally Erwin Chemerinsky, The Price of Asking the Wrong Question: An Essay on Constitutional Scholarship and Judicial Review, 62 TEX. L. Rev. 1207 (1984).

224. See generally Antonin Scalia, A Matter of Interpretation (1997).

225. 490 U.S. 642 (1989). 
majority's opinion perfunctorily rejects a longstanding rule of law and underestimates the probative value of evidence of a racially stratified work force. I cannot join this latest sojourn into judicial activism."226

To be sure, Justice Stevens's charge of "judicial activism" in Ward's Cove has a number of dimensions, including a charge of disregarding precedent. But also present is the charge that the Wards Cove majority did not properly weigh or acknowledge the "meaning and purpose of Title VII." At least some justices in the majority would readily admit, as a matter of interpretive approach, that they would give little or no weight to the "purpose" of a statute if they considered its text to be unambiguous. Thus, Justice Stevens could be seen as labeling this approach to statutory interpretation "activist." While it is undoubtedly his prerogative to do so, the exchange between Justice Stevens and the majority illustrates a way in which the label of "judicial activism" can obscure deeper issues: labeling one interpretive methodology "activist" does not illuminate the underlying dispute or serve as a constructive argument against one interpretive methodology or another.

Notwithstanding these difficulties, judges often find much to agree on in their respective methodologies, at least outside the constitutional context. Yet, even those who agree on the judicial canons of interpretation can disagree over the result of a particular case. This happened when Alberto Gonzales, as a Justice of the Supreme Court of Texas, condemned fellow Justice Priscilla Owen's interpretation of a statute as "an unconscionable act of judicial activism."227 Gonzales contended that Owen disregarded the text and legislative history of Texas's Parental Notification Act in order to reach her conclusion. Although Owen agreed that the text and history of a statute are the touchstones of statutory interpretation, she came to a different conclusion. Therefore, one reading of Gonzales's statement is that Owen employed these tools of statutory interpretation improperly.

As shown above, "judicial activism" can have at least two different meanings within this definition. First, as in Wards Cove, it can mean that a judge uses different (in kind or number) tools to make a decision, compared to what another judge would have used. This can occur because a judge makes a mistake, or because her judicial philosophy requires that she not avail herself of certain interpretive guides. Second, and more usefully, it can mean that two people agree on what tools should be used to make a decision, but disagree on how to apply the tools in a particular case.

\section{E. Result-Oriented Judging}

This species of judicial activism differs in kind from the previous four because it has a scienter element. Ninth Circuit Judge Diarmuid

226. Id. at 663 (citations omitted).

227. In re Doe, 19 S.W.3d 346, 366 (Tex. 2000). 
O'Scannlain defines it as follows: "Judicial activism means not the mere failure to defer to political branches or to vindicate norms of predictability and uniformity; it means only the failure to do so in order to advance another, unofficial objective."228 In other words, a decision is "activist" only when (a) the judge has an ulterior motive for making the ruling; and (b) the decision departs from some "baseline" of correctness. ${ }^{229} \mathrm{How}$ "activist" the decision is depends on how far it deviates from this baseline.

This definition is attractive in the abstract, but as Judge O'Scannlain notes, "Judicial activism is not always easily detected, because the critical elements of judicial activism either are subjective or defy clear and concrete definition." 230 There is rarely smoking gun evidence of an ulterior motive, and it can be exceedingly difficult to "establish a non-controversial benchmark by which to evaluate how far from the 'correct' decision the supposedly activist judge has strayed." 231 Nevertheless, this definition seems particularly useful, if only because the scienter element limits the universe of "activist" decisions more than any of the preceding definitions.

\section{CONCLUSION}

The previous sections demonstrate that judicial activism is not a monolithic concept. Rather, it can represent a number of distinct jurisprudential ideas that are worthy of further investigation. For example, when scholars suggest that striking down arguably constitutional actions of other branches is judicial activism, they invite debate over the age-old questions of how one can best interpret the Constitution, and what should be the proper scope of judicial review in our tripartite system of government. Similarly, a charge of judicial activism as disregarding precedent raises complex issues about the nature of a judicial holding, and the amount of deference owed to different types of precedent. Indeed, each of the definitions discussed in Part II invites subsidiary questions that are as important as they are difficult to resolve.

228. Diarmuid F. O'Scannlain, On Judicial Activism, OPEN SPACES Q., (Feb. 29, 2004), at http://www.open-spaces.com/article-v3nl-oscannlain.php. Howard Bashman, proprietor of the popular "How Appealing" appellate law blog, defines judicial activism in a similar way. "l would define 'judicial activism' to mean the actions of judges who do whatcver is necessary to rule as they personally prefer, regardless of what existing law provides." See the Sunday, November 10, 2002, entry entitled "Judicial activism'-easy to criticize, but hard to define and identify," at http://appellateblog.blogspot.com/2002_11_01_appellateblog_archive.html.

229. It is useful to compare this definition with what Professor William P. Marshall calls "partisan activism." William P. Marshall, Conservatives and the Seven Sins of Judicial Activism, 73 U. CoLo. L. REv, 1217, 1245-53 (2002) (partisan activism occurs "when the judiciary uses its power to further a partisan agenda."). Though Judge O'Scannlain and Professor Marshall are on opposite ends of the political spectrum, they describe judicial activism in similar terms.

230. O'S cannlain, supra note 228.

231. Id. 
The moments in the history of judicial activism profiled in Part I of this Comment add depth and texture to these definitions by showing how the term was originally used. Arthur Schlesinger's insightful and thoughtprovoking profile of the 1947 Supreme Court used the term "judicial activism" to convey fundamental ideas about law, politics, and the judicial role to a generalist audience. Edward McWhinney continued Schlesinger's tradition within legal academia, successfully treating judicial activism as a serious topic worthy of scholarly inquiry.

In spite of these early examples, many will find Judge Hutcheson's imprecise and less-than-constructive invocations of the term to be the modern norm. They would agree with Judge Easterbrook's observation that the label of "judicial activism" is often akin to name-calling, a shorthand for "Judges Behaving Badly."232 They will sympathize with Professor Randy Barnett's view that the term, "while clearly pejorative, is generally empty."233

Justice Scalia has voiced a version of this criticism. During oral arguments for Republican Party of Minnesota v. Kelly, ${ }^{234}$ he claimed that calling oneself a strict constructionist while criticizing others for being judicial activists "doesn't mean anything. It doesn't say whether you're going to adopt the incorporation doctrine, whether you believe in substantive due process. It's totally imprecise. It's just nothing but fluff."235

To a point, Justice Scalia is right. Today, a charge of "judicial activism" standing alone means little or nothing because the term has acquired so many distinct and even contradictory meanings. Nevertheless, when explained carefully, the term can be a starting point for meaningful conversation about the judicial craft, an opportunity to ask the subsidiary questions that go beyond the superficial. This Comment is an invitation to do just that.

232. Easterbrook, supra note 1, at 1401.

233. Barnett, supra note 12, at 1276.

234. 534 U.S. 1054 (2001).

235. No Unanimity on Holding on to High Esteem, WASH. Post, Apr. 1, 2002, at A13. And this is nothing new. Nearly fifty years earlier, a legal scholar sounded the same theme, saying that the concepts of judicial activism and judicial restraint are "inadequate to the task of determining the judicial philosophy of a particular justice." Paul A. Weidner, Justice Jackson and the Judicial Function, 53 MiCH. L. REv. 567, 594 (1955). 
